\title{
Influence of Ligand Architecture in Tuning Reaction Bifurcation Pathways for Chlorite Oxidation by Non-Heme Iron Complexes
}

DOI:

10.1021/acs.inorgchem.6b01384

\section{Document Version \\ Accepted author manuscript}

Link to publication record in Manchester Research Explorer

Citation for published version (APA):

Barman, P., Faponle, A. S., Vardhaman, A. K., Angelone, D., Löhr, A. M., Browne, W. R., Comba, P., Sastri, C. V., \& De Visser, S. (2016). Influence of Ligand Architecture in Tuning Reaction Bifurcation Pathways for Chlorite Oxidation by Non-Heme Iron Complexes. Inorganic Chemistry: including bioinorganic chemistry , 55(20), 1017010181. https://doi.org/10.1021/acs.inorgchem.6b01384

\section{Published in:}

Inorganic Chemistry: including bioinorganic chemistry

\section{Citing this paper}

Please note that where the full-text provided on Manchester Research Explorer is the Author Accepted Manuscript or Proof version this may differ from the final Published version. If citing, it is advised that you check and use the publisher's definitive version.

\section{General rights}

Copyright and moral rights for the publications made accessible in the Research Explorer are retained by the authors and/or other copyright owners and it is a condition of accessing publications that users recognise and abide by the legal requirements associated with these rights.

\section{Takedown policy}

If you believe that this document breaches copyright please refer to the University of Manchester's Takedown Procedures [http://man.ac.uk/04Y6Bo] or contact uml.scholarlycommunications@manchester.ac.uk providing relevant details, so we can investigate your claim.

\section{OPEN ACCESS}




\section{Influence of ligand architecture in tuning reaction bifurcation pathways for chlorite oxidation by nonheme iron complexes.}

Prasenjit Barman, ${ }^{\dagger}$ Abayomi S. Faponle, ${ }^{\ddagger}$ Anil Kumar Vardhaman, ${ }^{\dagger, \S}$ Davide Angelone, ${ }^{\perp}$ AnnaMaria Löhr, ${ }^{\diamond}$ Wesley R. Browne, ${ }^{\perp}$ Peter Comba, ${ }^{*}$ Chivukula V. Sastri ${ }^{* \dagger}$ and Sam P. de Visser ${ }^{*}$

${ }^{\dagger}$ Department of Chemistry, Indian Institute of Technology Guwahati, 781039, Assam, India

${ }^{\perp}$ Stratingh Institute for Chemistry, Faculty of Mathematics and Natural Sciences, University of Groningen, Nijenborgh 4, 9747 AG Groningen, The Netherlands

${ }^{\diamond}$ Heidelberg University, Anorganisch-Chemisches Institut and Interdisciplinary Center for Scientific Computing (IWR), Im Neuenheimer Feld 270, 69120 Heidelberg, Germany

${ }^{\ddagger}$ Manchester Institute of Biotechnology and School of Chemical Engineering and Analytical Science, The University of Manchester, 131 Princess Street, Manchester M1 7DN, United Kingdom 
ABSTRACT: Reaction bifurcation processes are often encountered in the oxidation of substrates by enzymes and generally lead to a mixture of products. One particular bifurcation process that is common in biology relates to electron transfer versus oxygen atom transfer processes by high valent iron(IV)-oxo complexes, which Nature uses for the oxidation of metabolites and drugs. In biomimicry and bioremediation an important reaction relates to the detoxification of $\mathrm{ClO}_{\mathrm{x}}{ }^{-}$in water, which can lead to a mixture of products through bifurcated reactions. Herein, we report the first three water soluble nonheme iron(II) complexes that can generate chlorine dioxide from chlorite at ambient temperature and physiological $\mathrm{pH}$. These complexes are highly active oxygenation oxidants and convert $\mathrm{ClO}_{2}^{-}$into either $\mathrm{ClO}_{2}$ or $\mathrm{ClO}_{3}^{-}$via high-valent iron(IV)-oxo intermediates. We characterize the short-lived iron(IV)-oxo species and establish rate constants for the bifurcation mechanism leading to $\mathrm{ClO}_{2}$ and $\mathrm{ClO}_{3}{ }^{-}$products. We show that the ligand architecture of the metal center plays a dominant role by lowering the reduction potential of the metal center. Our experiments are supported by computational modelling and a predictive valence bond model highlights the various factors relating to substrate and oxidant that determine the bifurcation pathways and explains the origins of the product distributions. Our combined kinetic, spectroscopic and computational studies reveal the key components necessary for the future development of efficient chlorite oxidation catalysts. 


\section{Introduction.}

Iron is ubiquitous in life and has a relatively high abundance. Nature has developed many iron complexes for a multitude of functions ranging from electron transfer and oxygen transport to oxidation catalysis. Therefore, iron enzymes are involved in vital biosynthesis and biodegradation processes in the body. There are two classes, the heme and nonheme iron enzymes. The former have an array of biochemical functions ranging from enzymatic catalysis (monoxygenases, e.g., the cytochromes $\left.\mathrm{P}_{450}\right)^{2}$ and detoxification by peroxidases and catalases, ${ }^{3}$ to oxygen transport (hemoglobin) ${ }^{4}$ and electron-transfer (e.g., cytochrome $c) .{ }^{5}$ Nonheme iron proteins act as dioxygenases in the metabolism of cysteine, ${ }^{6}$ DNA base repair ${ }^{7}$ and biosynthesis pathways, ${ }^{8}$ e.g., hydroxyproline. Finally, metal clusters, such as iron-sulfur clusters, are involved in electron transfer, whereby they relay electrons between a redox partner to a catalytically active site of an enzyme. ${ }^{9}$ Often iron containing biomolecules can react via several possible reaction channels leading to bifurcation pathways of which the product distributions are dependent on the structure and chemical properties of the metal center.

A common approach in mechanistic bioinorganic chemistry is to synthesize a biomimetic model that shares key structural and electronic features and study shortlived intermediates relevant to the enzymatic catalytic cycle, ${ }^{10}$ to probe the effects of the protein, the local environment and the nature of the transition metal center. ${ }^{11} \mathrm{~A}$ common problem associated with biomimetic oxidants is that they may react via multiple reaction channels leading to bifurcation pathways. In biotechnology, bifurcation often is to be avoided and hence, understanding the chemical origin and nature of bifurcation pathways is essential.

Several examples on modifying bifurcation mechanisms and their corresponding product distributions and regioselectivities have been described. For instance, Fukuzumi and co-workers ${ }^{12}$ investigated the electron transfer versus oxygen atom transfer mechanisms of a nonheme iron(IV)-oxo complex and found the former to be enhanced by the addition of perchloric acid. Nam et $\mathrm{al}^{13}$ showed that by replacing the axial ligand in an iron(IV)oxo porphyrin cation radical model, a regioselectivity change from aromatic to aliphatic hydroxylation of ethylbenzene occurred. Clearly, subtle changes to the active oxidant or its environment affect the regioselectivity and bifurcation of the reaction processes and consequently the product distributions.

In recent work, we investigated a biomimetic nonheme iron model, $\left[\mathrm{Fe}^{\mathrm{II}}\left(\mathrm{N}_{4} \mathrm{Py}\right)\right]^{2+}$ with $\mathrm{N}_{4} \mathrm{Py}=\mathrm{N}, \mathrm{N}-\mathrm{bis}(2-$ pyridylmethyl)-bis(2-pyridyl)methylamine (Figure 1), and reacted it with terminal oxidants to form the corresponding iron(IV)-oxo and iron(IV)-tosylimido complexes. ${ }^{14}$ It was shown that the system reacted by competitive electron transfer or atom transfer with substrates. To gain further insight into bifurcation pathways between elec- tron and atom transfer processes, we decided to look into an environmentally relevant reaction, namely the detoxification of $\mathrm{ClO}_{2}^{-}$in drinking water. Chlorine oxides $\left(\mathrm{ClO}_{\mathrm{x}}^{-}\right.$ ) are used extensively for cleaning and health care purposes with functions ranging from bleaching to disinfection. The high solubility of chlorine oxides in water and their long lifetime in the environment, however, has resulted in major ecological problems, specifically with drinking water. From an environmental perspective the bioremediation of $\mathrm{ClO}_{\mathrm{x}}{ }^{-}$from water supplies is performed efficiently by perchlorate respiring bacteria. These achieve this reactivity using two enzymes, perchlorate reductase, which catalyzes the conversion of perchlorate to chlorate and subsequently to chlorite, and chlorite dismutase that converts chlorite to chloride $\left(\mathrm{Cl}^{-}\right)$and molecular oxygen $\left(\mathrm{O}_{2}\right){ }^{15,16}$ Chlorite dismutase, however, is an iron-heme enzyme and little is known of nonheme iron centers for the activation of chlorine oxides. Therefore, we decided to investigate nonheme iron complexes and their reactivity with $\mathrm{ClO}_{2}{ }^{-}$. To further understand the nature of bifurcation pathways, we used two types of iron(II) precatalysts with $\mathrm{N}_{4} \mathrm{Py}$ as well as a pentadentate bispidine as ligands (dimethyl 2,4-di(2-pyridyl)3-(pyridin-2-ylmethyl)-7methyl-3,7-diazabicyclo [3.3.1]nonan-9-one-1,5dicarboxylate, $\left.\mathrm{L}^{1}\right) .{ }^{17}$ We chose the $\left[\mathrm{Fe}^{\mathrm{II}}\left(\mathrm{L}^{1}\right)\right]^{2+}$ complex because it is known to react efficiently with thioanisoles to form sulfoxides with rate constants considerably faster than those obtained for $\left[\mathrm{Fe}^{\mathrm{II}}\left(\mathrm{N}_{4} \mathrm{Py}\right)\right]^{2+}{ }^{18}$ Our combined experimental (kinetics and spectroscopy) and computational study using these iron(IV)-oxo complexes shows dramatic differences in electron transfer versus oxygen atom transfer reactivities. These differences are analyzed in detail and approaches are proposed as to how to modify these oxidants further to target specific products. The studies are rationalized with thermochemical and valence bond models. 


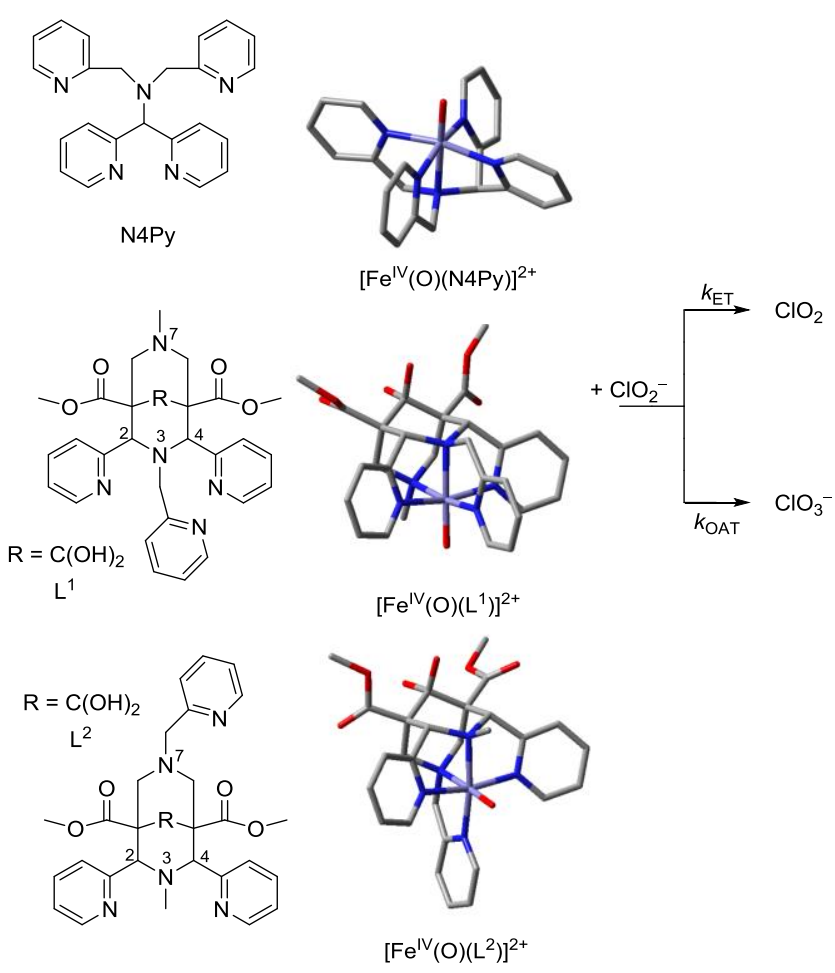

Figure 1. Oxidants and chemical reactions investigated in this work.

\section{Methods.}

Materials. All chemicals were obtained from Aldrich Chemical Co., and were purchased of the best available purity and used without further purification unless stated otherwise. Reactions were carried out and monitored in deionized water purified in a Millipore Milli-Q water purification system. Acetate buffer was prepared freshly by mixing sodium acetate and acetic acid to obtain a solution at $\mathrm{pH}$ 5. Sodium chlorite was purchased from Sigma and recrystallized twice from an ethanol/water mixture. The ligands ( $\mathrm{N}_{4} \mathrm{Py}, \mathrm{L}^{1}$ and $\mathrm{L}^{2}=$ dimethyl 2,4-di(2-pyridyl)3-methyl-7-(pyridin-2-ylmethyl)-3,7-diazabicyclo[3-3.1] nonan-9-one-1,5-dicarboxylate) were prepared by literature procedures. ${ }^{19,20}$ The corresponding $\left[\mathrm{Fe}^{\mathrm{II}}\left(\mathrm{N}_{4} \mathrm{Py}\right)\left(\mathrm{NCCH}_{3}\right)\right](\mathrm{OTf})_{2}, \quad\left[\mathrm{Fe}^{\mathrm{II}}\left(\mathrm{L}^{1}\right)\right]\left(\mathrm{BF}_{4}\right)_{2}$ and $\left[\mathrm{Fe}^{\mathrm{II}}\left(\mathrm{L}^{2}\right)\right]\left(\mathrm{BF}_{4}\right)_{2}$ were prepared and characterized by purified procedures. ${ }^{14 \mathrm{a}, 19,20 \mathrm{~b}}$

Instrumentation. UV/vis absorption spectra were recorded on a Hewlett Packard 8453 spectrophotometer equipped with either constant temperature circulating water bath or a liquid nitrogen cryostat (Unisoku) with a temperature controller. Absorption changes were measured as a function of time and enabled us to derive firstorder rate constants for the reactions involved. High Resolution electrospray ionization (ESI) mass spectrometry (MS) spectra were recorded on a Waters (Micromass MS Technologies) quadruple time-of-flight (Q-TOF) Premier mass spectrometer by infusing samples directly into the

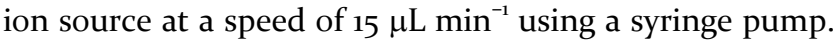

The spray voltage was set to $2 \mathrm{kV}$ and the capillary temperature at $80^{\circ} \mathrm{C}$.

Reactivity studies. Following calibrations described previously, ${ }^{21}$ reactions were run in a $10 \mathrm{~mm}$ path length quartz cuvette by monitoring the changes in the spectra of the reaction mixtures over time. Rate constants were determined by fitting the time-dependent change in absorbance of the intermediates under study. First-order rate constants were determined in triplicate with a standard deviation of $<10 \%$.

Chlorine dioxide analysis. $\mathrm{ClO}_{2}$ content was analyzed by extraction of the aqueous solution with diethyl ether and subsequent characterization by negative ion mode ESI-MS (inset of Figure 2a), and by kinetic data (Figure 2b). ${ }^{22}$ This method was validated by (i) bubbling $\mathrm{ClO}_{2}$ through an aqueous solution and characterizing the $\mathrm{ClO}_{2}$ as described above and (ii) extracting a solution of chlorite $\left(\mathrm{NaClO}_{2}, 8 \mathrm{mM}\right)$ as described above, with the result that no ESI-MS signal at $m / z=67.14$ was observed since $\mathrm{ClO}_{2}{ }^{-}$is insoluble in diethyl ether.

o-Tolidine product analysis. Chlorate content was determined using 3,3'-dimethyl-4,4'-diaminobiphenyl (otolidine) as described previously. ${ }^{23}$ A typical reaction was carried out with $10 \mu \mathrm{M} \mathrm{Fe}^{\mathrm{II}}$ oxidant with $4.0 \mathrm{mM} \mathrm{NaClO}{ }_{2}$ and $1 \mathrm{mM}$ o-tolidine in acetate buffer at ambient temperature. The o-tolidine product was extracted from the aqueous medium into ethylacetate and analyzed by ESI-MS.

Computation. All calculations utilize density functional theory as implemented in Gaussian-09. ${ }^{24}$ Following extensive benchmark and calibration procedures from the past, ${ }^{25}$ we used the unrestricted B3LYP method throughout. $^{26}$ Each structure was subjected to a full geometry optimization and characterized as a local minimum using an analytical frequency calculation at the UB $3 L Y P / B_{1}$ level of theory: BS1 stands for $\operatorname{LACVP}(\mathrm{Fe})$ and $6-31 \mathrm{G}$ (rest of the atoms). ${ }^{27}$ This combination of method and basis set was shown previously to reproduce experimentally determined free energies of activation and product distributions well. ${ }^{28}$ In order to improve the energetics single point calculations were done with a triple- $\zeta$ type basis set $\mathrm{BS}_{2}\left(\mathrm{LACV}_{3} \mathrm{P}+\right.$ with core potential on $\mathrm{Fe}$ and $6-311+\mathrm{G}^{*}$ on the rest of the atoms). Initially, these single points were done in the gas-phase but later also in a polarized continuum model with a dielectric constant mimicking water. Free energies reported in this work use electronic energies calculated at $\mathrm{UB}_{3} \mathrm{LYP} / \mathrm{BS}_{2} / / \mathrm{UB}_{3} \mathrm{LYP} / \mathrm{BS}_{1}$ and include zero-point, thermal (at 298K), solvent and entropic corrections.

All metal complexes were calculated in the lowest lying spin multiplicities, i.e. doublet/quartet/sextet or singlet/triplet/quintet, but for the calculation of the reaction 
energies only the lowest lying spin state of each structure was used. Test calculations with alternative density functional methods (BP86, $\left.{ }^{29} \mathrm{OPBE},{ }^{30} \mathrm{Mo} 6,{ }^{31} \mathrm{~B}_{3} \mathrm{PW} 91\right)^{26 \mathrm{a}, 32}$ predicted the same trends and only gave minor changes to the relative energies. Furthermore, test calculations that included the effect of dispersion ${ }^{33}$ were found to give minimal changes to the energetics. Finally, the reproducibility and reliability of the computational methods was tested by calculating the gas-phase electron affinities of $\mathrm{ClO}$, $\mathrm{ClO}_{2}$ and $\mathrm{ClO}_{3}$ and compared to those from the NIST database. ${ }^{34}$ As follows from Table $\mathrm{S}_{7}$ in the Supporting Information the electron affinities of $\mathrm{ClO}$ and $\mathrm{ClO}_{3}$ are reproduced to within $1.2 \mathrm{kcal} \mathrm{mol}^{-1}$. Whenever possible, the experimental values of the electron affinities were used.

In a final set of calculations, we investigated the potential energy landscape for the reaction of the iron(IV)-oxo complex with $\mathrm{ClO}_{2}^{-}$to form each of the individual products. Firstly, the free energy of activation for electron transfer $\left(\Delta \mathrm{G}_{\mathrm{ET}}^{\ddagger}\right)$ was calculated from the Marcus equations using previously described methods ${ }^{35}$ from the driving force for the electron transfer reaction $\left(\Delta \mathrm{G}_{\mathrm{ET}}\right.$, Eq 1) and the solvent reorganization energy $\lambda_{0}$. In eqs 1 and 2 , $\mathrm{N}_{\mathrm{A}}$ represents Avogadro's number, e is the elementary charge and $\varepsilon_{0}$ is the permittivity of vacuum. The static and optical dielectric constants $\left(\varepsilon_{\mathrm{s}}\right.$ and $\left.\varepsilon_{\mathrm{op}}\right)$ were taken from the Gaussian calculation and had values of 78.36 (water) and 1.78, respectively. The hard sphere radii (in $\AA$ ) of the donor and acceptor molecules of the electron are labelled with $r_{1}$ and $r_{2}$.

$$
\begin{aligned}
& \Delta G_{E T}^{\neq}=\frac{\lambda_{0}}{4}\left(1+\frac{\Delta G_{E T}}{\lambda_{0}}\right)^{2} \\
& \lambda_{0}=\frac{N_{A} e^{2}}{4 \pi \varepsilon_{0}}\left(\frac{1}{\varepsilon_{o p}}-\frac{1}{\varepsilon_{s}}\right)\left(\frac{1}{2 r_{1}}+\frac{1}{2 r_{2}}-\frac{1}{r_{1}+r_{2}}\right)
\end{aligned}
$$

Finally, the attack of $\mathrm{ClO}_{2}^{-}$on the iron(IV)-oxo species was investigated through extensive geometry scans initially, whereby either the $\mathrm{Cl}-\mathrm{O}$ or $\mathrm{FeO}-\mathrm{O}$ distances were varied in a stepwise manner. In these calculations each geometry step represented a full geometry optimization with fixed $\mathrm{Cl}-\mathrm{O}$ or $\mathrm{FeO}-\mathrm{O}$ distance. The maxima of these scans were then subjected to a full transition state search and led to the transition states reported here. Free energies reported here use energies obtained at UB3LYP/BS2//UB3 $2 Y P / B S 1$ with zero-point, thermal, entropic and solvent corrections included at $298 \mathrm{~K}$.

To test the effect of solvation on the optimized reactant and transition state structures we ran a full geometry optimization with solvent model included; however, only minor differences in geometry were obtained (Supporting Information). 


\section{Results and Discussion.}

The disproportionation of $\mathrm{ClO}_{2}{ }^{-}$, under the influence of iron(II) complexes, in water was studied with the focus on the product distributions as a function of the ligand structure and electronic characteristics. $\mathrm{ClO}_{2}{ }^{-}$can react via any of several reaction pathways, and as such a variety of products can be expected, including $\mathrm{ClO}_{2}$ and $\mathrm{ClO}_{3}{ }^{-}$. We established the reactivities of the iron(II) complexes with $\mathrm{ClO}_{2}{ }^{-}$, and subsequently characterize short-lived intermediates formed during the reactions, determine reaction products and identify rate-limiting steps. Computational modeling of the reaction mechanisms and reactivity patterns was performed to rationalize the product distributions and understand the chemical differences between the oxidations.
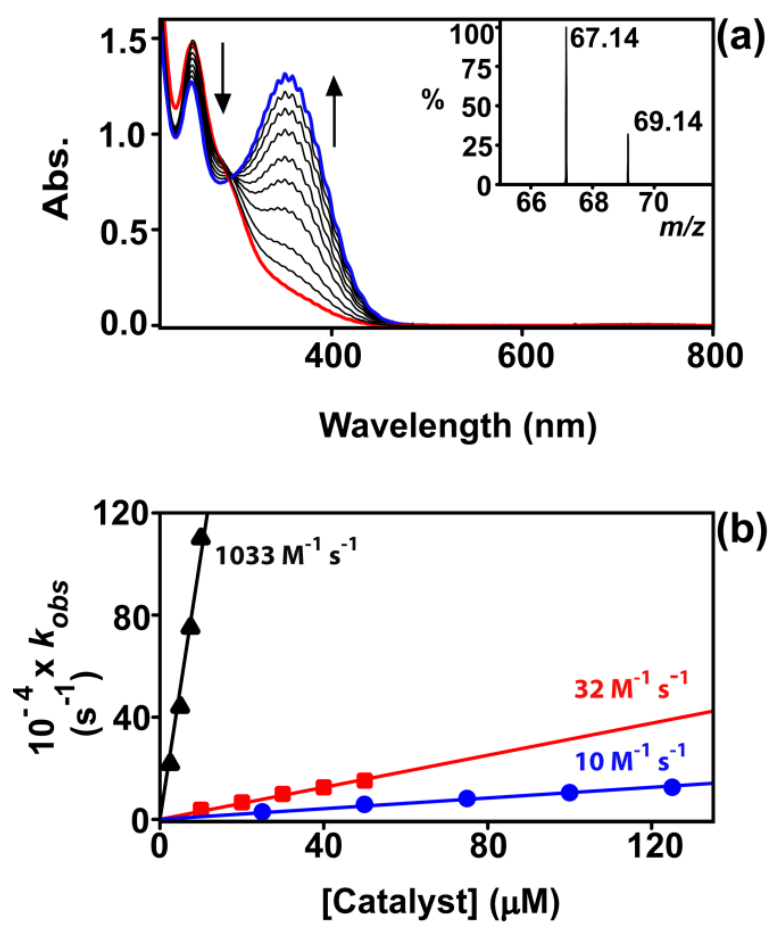

Figure 2. Spectroscopic and kinetics studies for the reaction of iron(II) complexes with $\mathrm{ClO}_{2}^{-}$. (a) Changes in the UV/Vis absorption spectra at a scan interval of $180 \mathrm{~s}$ upon the addition of $8.0 \mathrm{mM} \mathrm{NaClO}$, to $50 \mu \mathrm{M}\left[\mathrm{Fe}^{\mathrm{II}}\left(\mathrm{L}^{1}\right)\right]^{2+}$ in an acetate buffer. Inset shows ESI-MS of products obtained. (b) Second order rate constants obtained for the reaction of $\mathrm{ClO}_{2}{ }^{-}$with $\left[\mathrm{Fe}^{\mathrm{II}}\left(\mathrm{N}_{4} \mathrm{Py}\right)\right]^{2+}$ (black line), $\left[\mathrm{Fe}^{\mathrm{II}}\left(\mathrm{L}^{1}\right)\right]^{2+}$ (blue line) and $\left[\mathrm{Fe}^{\mathrm{II}}\left(\mathrm{L}^{2}\right)\right]^{2+}$ (red line).

Reactivity of iron(II) complexes. The reactivity of sodium chlorite with nonheme iron(II) complexes with pentadentate ligands $\mathrm{N}_{4} \mathrm{Py}, \mathrm{L}^{1}$ and $\mathrm{L}^{2}$ was investigated in acetate buffer $(50 \mathrm{mM})$ at $\mathrm{pH} 5.0$ at $25{ }^{\circ} \mathrm{C}$ (Figure 1). Addition of the iron(II) complexes to solutions of sodium chlorite $\left(\mathrm{NaClO}_{2}\right)$, there is an increase in absorbance at 360 $\mathrm{nm}$, characteristic for the formation of chlorine dioxide. ${ }^{36}$
Figure 2a shows the spectral changes for the reaction of $\left[\mathrm{Fe}^{\mathrm{II}}\left(\mathrm{L}^{1}\right)\right]^{2+}$ with $\mathrm{ClO}_{2}^{-}$, whereas those involving the $\left[\mathrm{Fe}^{\mathrm{II}}\left(\mathrm{L}^{2}\right)\right]^{2+}$ and $\left[\mathrm{Fe}^{\mathrm{II}}\left(\mathrm{N}_{4} \mathrm{Py}\right)\right]^{2+}$ complexes are given in the Supporting Information, Figures $\mathrm{S}_{4}$ and $\mathrm{S}_{5}$, where the same spectral changes are observed. The consumption of chlorite in the process is monitored by the decrease in absorbance at $260 \mathrm{~nm}\left(\varepsilon_{260}=154 \mathrm{M}^{-1} \mathrm{~cm}^{-1}\right)$ as well as the concomitant formation of $\mathrm{ClO}_{2}$ as measured through the increase in absorption at $360 \mathrm{~nm}\left(\varepsilon_{360}=1250 \mathrm{M}^{-1} \mathrm{~cm}^{-1}\right)$.

Negative ion mode ESI-MS of a diethyl ether extract of the reaction mixture (Inset of Figure 2a) shows a signal with an isotopic pattern consistent with $\mathrm{ClO}_{2}$ formation $(m / z=67.14)$. The reaction reaches a maximum in conversion within 40 min with oxidant loading of $10 \mu \mathrm{M}$ at $25^{\circ} \mathrm{C}$ and $\mathrm{pH}$ 5.0.

The first-order rate constants as a function of oxidant concentration (Figure $2 \mathrm{~b}$, Table 1 ) for the reaction of $\mathrm{ClO}_{2}{ }^{-}$with $\left[\mathrm{Fe}^{\mathrm{II}}\left(\mathrm{N}_{4} \mathrm{Py}\right)\right]^{2+},\left[\mathrm{Fe}^{\mathrm{II}}\left(\mathrm{L}^{1}\right)\right]^{2+}$ and $\left[\mathrm{Fe}^{\mathrm{II}}\left(\mathrm{L}^{2}\right)\right]^{2+}$ were determined. The second-order rate constants of $k_{2}=10 \mathrm{M}^{-}$ ${ }^{1} \mathrm{~s}^{-1}$ and $32 \mathrm{M}^{-1} \mathrm{~s}^{-1}$, respectively, for $\left[\mathrm{Fe}^{\mathrm{II}}\left(\mathrm{L}^{1}\right)\right]^{2+}$ and $\left[\mathrm{Fe}^{\mathrm{II}}\left(\mathrm{L}^{2}\right)\right]^{2+}$ (Figure $2 \mathrm{~b}$ ) were determined from the dependence of the rate of generation of $\mathrm{ClO}_{2}$ on the initial concentrations of the iron(II) complexes. These reaction rates correspond to a maximum yield of 13 and $10 \%$ with respect to iron for $\left[\mathrm{Fe}^{\mathrm{II}}\left(\mathrm{L}^{1}\right)\right]^{2+}$ and $\left[\mathrm{Fe}^{\mathrm{II}}\left(\mathrm{L}^{2}\right)\right]^{2+}$, respectively. Our results contradict previous substrate sulfoxidation studies by $\left[\mathrm{Fe}^{\mathrm{II}}\left(\mathrm{L}^{1}\right)\right]^{2+}$ and $\left[\mathrm{Fe}^{\mathrm{II}}\left(\mathrm{L}^{2}\right)\right]^{2+}$, in which the latter was 100 times more reactive, whereas it reacts 40 times faster in hydrogen atom abstraction reactions. ${ }^{18}$ In comparison to the bispidine-type complexes, addition of 10 $\mu \mathrm{M}\left[\mathrm{Fe}^{\mathrm{II}}\left(\mathrm{N}_{4} \mathrm{Py}\right)\right]^{2+}$ to chlorite $(4 \mathrm{mM})$ resulted in the immediate appearance of an absorption band at $360 \mathrm{~nm}$; characteristic of the formation of chlorine dioxide. The absorbance at $360 \mathrm{~nm}$ reaches a maximum with a second order rate constant of $1033 \mathrm{M}^{-1} \mathrm{~s}^{-1}$ and an overall yield of $16 \%$ of $\mathrm{ClO}_{2}$. As such, the $\left[\mathrm{Fe}^{\mathrm{II}}\left(\mathrm{N}_{4} \mathrm{Py}\right)\right]^{2+}$ complex reacts with rate constants that are at least 30 times higher than the fastest reacting bispidine complex. The yield of the $\mathrm{ClO}_{2}$ obtained here is in the line with previous studies of analogous manganese and ruthenium catalysts. ${ }^{37}$

Table 1 Data for the oxidation of $\mathrm{ClO}_{2}^{-}$in aqueous acetate buffer

\begin{tabular}{lccc}
\hline \multicolumn{1}{c}{ Complex } & $k_{2}\left(\mathrm{M}^{-1} \mathrm{~s}^{-1}\right)$ & $\% \mathrm{ClO}_{2}$ & $\mathrm{TON}$ \\
\hline$\left[\mathrm{Fe}^{\mathrm{II}}\left(\mathrm{L}^{1}\right)\right]^{2+}$ & 10 & 13 & 300 \\
{$\left[\mathrm{Fe}^{\mathrm{II}}\left(\mathrm{L}^{2}\right)\right]^{2+}$} & 32 & 10 & 775 \\
{$\left[\mathrm{Fe}^{\mathrm{II}}\left(\mathrm{N}_{4} \mathrm{Py}\right)\right]^{2+}$} & 1033 & 16 & 2796 \\
\hline
\end{tabular}



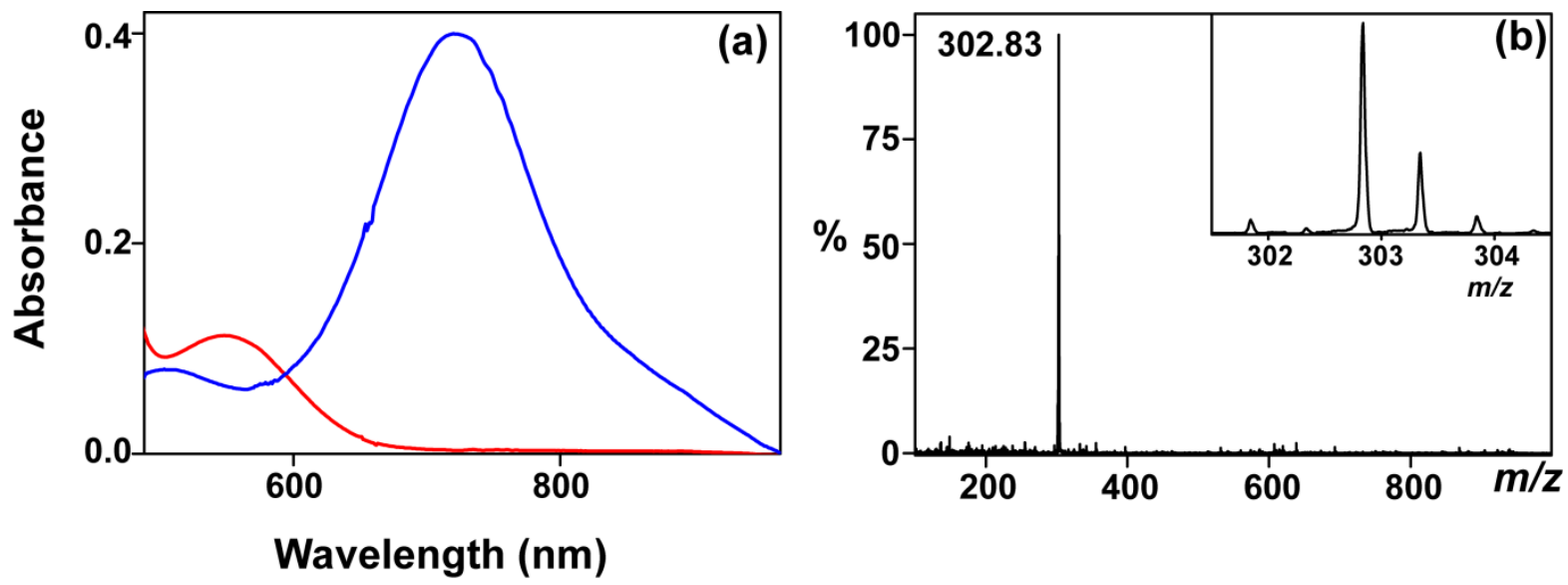

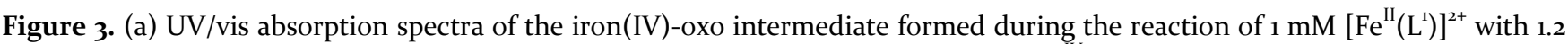
equiv. of $\mathrm{NaClO}_{2}$ at $298 \mathrm{~K}$ in acetate buffer at $\mathrm{pH}$ 5.o. (b) ESI-MS characterization of $\left[\mathrm{Fe}^{\mathrm{IV}}(\mathrm{O})\left(\mathrm{L}^{1}\right)\right]^{2+}$.

Characterization of iron(IV)-oxo intermediates. Identification of the formation of intermediates such as $\mathrm{Fe}^{\mathrm{IV}}(\mathrm{O})$ species could provide insight into the reaction mechanism between the iron(II) complexes with $\mathrm{ClO}_{2}^{-}$. Recent studies on the reactivity of nonheme manganese(II) complexes with $\mathrm{ClO}_{2}^{-}$showed that oxygen atom transfer occurred to form a manganese(IV)-oxo species and $\mathrm{ClO}^{-}$. The corresponding iron(IV)-oxo complexes $\left[\mathrm{Fe}^{\mathrm{IV}}(\mathrm{O})\left(\mathrm{L}^{1}\right)\right]^{2+},\left[\mathrm{Fe}^{\mathrm{IV}}(\mathrm{O})\left(\mathrm{L}^{2}\right)\right]^{2+}$ and $\left[\mathrm{Fe}^{\mathrm{IV}}(\mathrm{O})\left(\mathrm{N}_{4} \mathrm{Py}\right)\right]^{2+}$ have been characterized previously with UV/Vis absorption, resonance Raman, EPR and mass spectrometric methods. ${ }^{38,39}$

Figure 3 shows the UV/Vis absorption and mass spectrometric characterization of the iron(IV)-oxo species $\left[\mathrm{Fe}^{\mathrm{IV}}(\mathrm{O})\left(\mathrm{L}^{1}\right)\right]^{2+}$, and the corresponding spectra for the systems with ligands $\mathrm{L}^{2}$ and $\mathrm{N}_{4} \mathrm{Py}$ are given in the Supporting Information Figures S6 and $\mathrm{S}_{7}{ }^{18}$ Addition of 1.2 equiv of $\mathrm{NaClO}_{2}$ to $1 \mathrm{mM}$ solutions of the iron(II) complexes results in a change in the UV/Vis absorption spectra is observed with a NIR absorption band characteristic of iron(IV)-oxo complexes in near quantitative yields, which was confirmed by ESI-MS analysis: $\left[\mathrm{Fe}^{\mathrm{IV}}(\mathrm{O})\left(\mathrm{L}^{1}\right)\right]^{2+}$, $\left[\mathrm{Fe}^{\mathrm{IV}}(\mathrm{O})\left(\mathrm{L}^{2}\right)\right]^{2+}$ and $\left[\mathrm{Fe}^{\mathrm{IV}}(\mathrm{O})\left(\mathrm{N}_{4} \mathrm{Py}\right)\right]^{2+}$ with $\mathrm{m} / \mathrm{z}$ values close to the theoretical values were observed. Note that under stoichiometric conditions, the iron(IV)-oxo complex is the sole product of the reaction and $\mathrm{ClO}_{2}$ is not detected.

The data in Figure 3, therefore, provides evidence that the reaction of the iron(II) complexes with $\mathrm{ClO}_{2}{ }^{-}$proceeds through the formation of an iron(IV)-oxo intermediate (Eq 3). This iron(IV)-oxo species was characterized for all three pentacoordinated ligand systems and subsequently reacts with another molecule of chlorite through either electron transfer or oxygen atom transfer to form the final products and hence the overall reaction of two molecules of $\mathrm{ClO}_{2}^{-}$per iron center.

$$
\left[\mathrm{Fe}^{\mathrm{II}}\right]^{2+}+\mathrm{ClO}_{2}^{-} \rightarrow\left[\mathrm{Fe}^{\mathrm{IV}}(\mathrm{O})\right]^{2+}+\mathrm{ClO}^{-}
$$
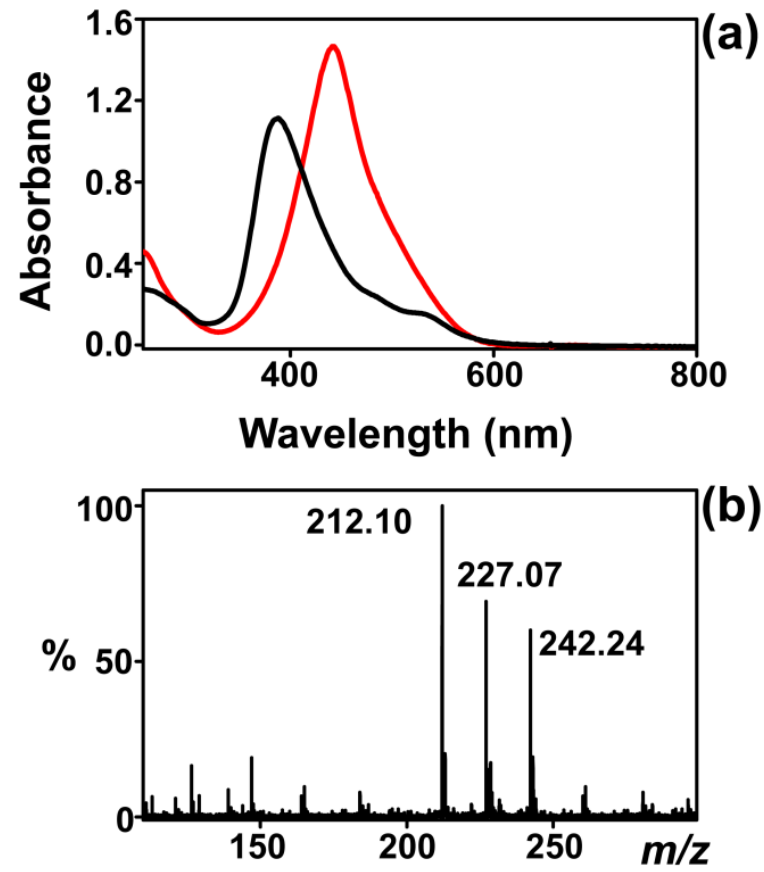

Figure 4. (a) UV/Vis absorption spectra of $\left[\mathrm{Fe}^{\mathrm{II}}\left(\mathrm{N}_{4} \mathrm{Py}\right)\right]^{2+}(10$ $\mu \mathrm{M}$, black line) and $\left[\mathrm{Fe}^{\mathrm{II}}\left(\mathrm{L}^{2}\right)\right]^{2+}(10 \mu \mathrm{M}$, red line) after reaction with $4.0 \mathrm{mM} \mathrm{NaClO}$, with o-tolidine $(40 \mu \mathrm{M})$ in acetate buffer. (b) ESI-MS spectra of products obtained from the reaction of $\mathrm{NaClO}_{2}$ with $\left[\mathrm{Fe}^{\mathrm{II}}\left(\mathrm{L}^{2}\right)\right]^{2+}$. 
Product distributions from bifurcation pathways. The reaction of an iron(IV)-oxo species with excess $\mathrm{ClO}_{2}^{-}$ can lead to products resulting from either electron transfer or oxygen atom transfer, Eq 4 and 5.

$$
\begin{aligned}
& {\left[\mathrm{Fe}^{\mathrm{IV}}(\mathrm{O})\right]^{2+}+\mathrm{ClO}_{2}^{-} \rightarrow\left[\mathrm{Fe}^{\mathrm{III}}(\mathrm{O})\right]^{+}+\mathrm{ClO}_{2}} \\
& {\left[\mathrm{Fe}^{\mathrm{IV}}(\mathrm{O})\right]^{2+}+\mathrm{ClO}_{2}^{-} \rightarrow\left[\mathrm{Fe}^{\mathrm{II}}\right]^{2+}+\mathrm{ClO}_{3}^{-}}
\end{aligned}
$$

The $\mathrm{ClO}_{2}$ content of the reaction mixture after reaction with $\left[\mathrm{Fe}^{\mathrm{II}}\left(\mathrm{L}^{1}\right)\right]^{2+},\left[\mathrm{Fe}^{\mathrm{II}}\left(\mathrm{L}^{2}\right)\right]^{2+}$ and $\left[\mathrm{Fe}^{\mathrm{II}}\left(\mathrm{N}_{4} \mathrm{Py}\right)\right]^{2+}$ was determined by extraction with diethyl ether followed by ESIMS analysis.

The content of $\mathrm{ClO}_{3}^{-}$in the product mixture was determined using o-tolidine, as described elsewhere. ${ }^{23}$ It should be noted that o-tolidine reacts with $\mathrm{ClO}_{3}{ }^{-}$but not with either $\mathrm{ClO}_{2}^{-}$or $\mathrm{ClO}_{2}$. Reaction of the iron(II) bispidine complexes with $\mathrm{NaClO}_{2}$ in acetate buffer in the presence of o-tolidine at ambient temperature results in the appearance of a band at $442 \mathrm{~nm}$ corresponding to $3,3^{\prime}$ dimethyl-4-amino-4'-nitrobiphenyl (Figure 4a). The ESIMS spectrum (after extraction) shows a signal at $\mathrm{m} / \mathrm{z}$ 242.24 corresponding to the oxidized product. In addition, a signal at $\mathrm{m} / \mathrm{z}=\mathbf{2 2 7 . 0 7}$ corresponding to the partially oxidized nitroso intermediate is observed. The reactions involved and products obtained are summarized in Scheme 1.

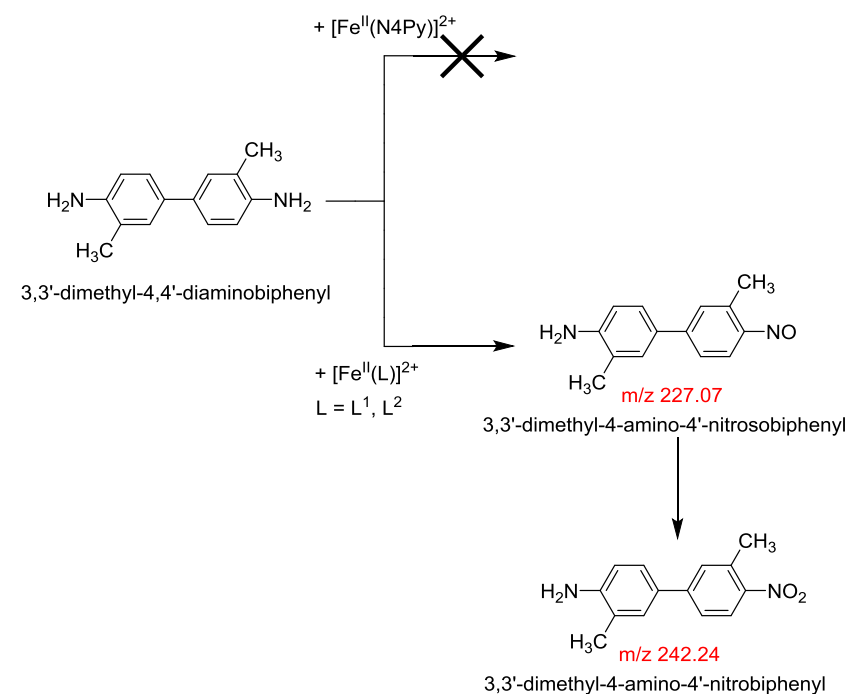

Scheme 1. Reaction of o-tolidine with iron(II) complexes.

In contrast, the reaction with $\left[\mathrm{Fe}^{\mathrm{II}}\left(\mathrm{N}_{4} \mathrm{Py}\right)\right]^{2+}$ did not result in the formation of products associated with the reaction of o-tolidine with $\mathrm{ClO}_{3}^{-}$. Instead a peak at $388 \mathrm{~nm}$ was observed in the UV/Vis absorption spectrum indicating the presence of ferric species. ${ }^{23}$ ESI-MS analysis of the organic extracted phase did not show significant formation of the nitro derivate, which may be a consequence of subsequent reaction in the oxidation of $\mathrm{ClO}_{2}^{-}$. Hence, the bispidine based complexes, $\left[\mathrm{Fe}^{\mathrm{II}}\left(\mathrm{L}^{1}\right)\right]^{2+}$ and $\left[\mathrm{Fe}^{\mathrm{II}}\left(\mathrm{L}^{2}\right)\right]^{2+}$ (see Supporting Information), react via oxygen atom transfer processes with the formation of $\mathrm{ClO}_{3}{ }^{-}$products as the dominant pathway, whereas $\left[\mathrm{Fe}^{\mathrm{II}}\left(\mathrm{N}_{4} \mathrm{Py}\right)\right]^{2+}$ reacts to yield $\mathrm{ClO}_{2}$ and related products through a one-electron transfer process.

In addition to the characterization of the iron(IV)-oxo species, $\mathrm{ClO}_{2}$ and $\mathrm{ClO}_{3}^{-}$, we made attempts to characterize additional short-lived intermediates during the reaction process, and in particularly focused on the UV-Vis, Infrared and EPR spectra of iron(III)-oxo and iron(III)hydroxo species. Unfortunately, these species are either not EPR active or the expected signal intensity is below the limits of detection. Furthermore, the UV/vis absorption spectra of such species are not sufficiently intense to be detected at the concentrations employed.

Computational modeling. The differences in the reactivity of chlorite with $\left[\mathrm{Fe}^{\mathrm{IV}}(\mathrm{O})\left(\mathrm{L}^{1}\right)\right]^{2+},\left[\mathrm{Fe}^{\mathrm{IV}}(\mathrm{O})\left(\mathrm{L}^{2}\right)\right]^{2+}$ and $\left[\mathrm{Fe}^{\mathrm{IV}}(\mathrm{O})\left(\mathrm{N}_{4} \mathrm{Py}\right)\right]^{2+}$ were investigated by density functional theory (DFT) methods, focusing on the thermochemistry, as well as, barriers to the reaction steps, with the aim of proposing an overall mechanism. Over 20 distinct chemical reactions involving $\mathrm{ClO}_{2}, \mathrm{ClO}_{2}^{-}, \mathrm{ClO}_{3}^{-}$and $\mathrm{ClO}^{-}$intermediates were considered including those in which the acetate ions, present in the buffer, are involved (Supporting Information Tables $\mathrm{S}_{15}-\mathrm{S}_{17}$ ).

Our initial focus was on the formation of the iron(IV)oxo intermediate, $\left[\mathrm{Fe}^{\mathrm{IV}}(\mathrm{O})\left(\mathrm{L}^{1}\right)\right]^{2+}$, from the reaction of either an iron(II) complex or a solvent (water) bound iron(II) resting state, $\left[\mathrm{Fe}^{\mathrm{II}}\left(\mathrm{H}_{2} \mathrm{O}\right)\left(\mathrm{L}^{1}\right)\right]^{2+}$, Figure 5. We took the energy differences for the lowest energy spin state structures, i.e. quintet for the iron(II) complexes and triplet for the iron(IV)-oxo species. The exchange of $\mathrm{H}_{2} \mathrm{O}$ with chlorite is exergonic by $6.9 \mathrm{kcal} \mathrm{mol}^{-1}$, which drops to $18.7 \mathrm{kcal} \mathrm{mol}^{-1}$ when the iron(II) complex is pentacoordinated. Whether a solvent molecule is bound to the sixth ligand position of the iron(II) complex has little effect on the formation of $\left[\mathrm{Fe}^{\mathrm{II}}\left(\mathrm{ClO}_{2}\right)\left(\mathrm{L}^{1}\right)\right]^{+}$. Dissociation of $\left[\mathrm{Fe}^{\mathrm{II}}\left(\mathrm{ClO}_{2}\right)\left(\mathrm{L}^{1}\right)\right]^{+}$into $\left[\mathrm{Fe}^{\mathrm{IV}}(\mathrm{O})\left(\mathrm{L}^{1}\right)\right]^{2+}$ and $\mathrm{ClO}^{-}$is also exergonic by $16.2 \mathrm{kcal} \mathrm{mol}{ }^{-1}$; therefore, the $\left[\mathrm{Fe}^{\mathrm{IV}}(\mathrm{O})\left(\mathrm{L}^{1}\right)\right]^{2+}$ should form readily in a mixture of the $\left[\mathrm{Fe}^{\mathrm{II}}\left(\mathrm{H}_{2} \mathrm{O}\right)\left(\mathrm{L}^{1}\right)\right]^{2+}$ and $\mathrm{ClO}_{2}^{-}$. The overall driving force $\left(\Delta \mathrm{G}_{\mathrm{f}}+\Delta \mathrm{G}_{\mathrm{f}_{2}}\right)$ for the formation of the $\left[\mathrm{Fe}^{\mathrm{IV}}(\mathrm{O})\left(\mathrm{L}^{1}\right)\right]^{2+}$ complex from $\left[\mathrm{Fe}^{\mathrm{II}}\left(\mathrm{H}_{2} \mathrm{O}\right)\left(\mathrm{L}^{1}\right)\right]^{2+}$ is $-23.1 \mathrm{kcal} \mathrm{mol}^{-1}$, whereas a value of $37.8 \mathrm{kcal} \mathrm{mol}^{-1}$ is found for the $\mathrm{N}_{4} \mathrm{Py}$ complex. Hence, both iron(II) complexes should rapidly form an iron(IV)oxo species with $\mathrm{ClO}_{2}^{-}$. The formation of the iron(IV)-oxo species upon reaction of $\left[\mathrm{Fe}^{\mathrm{II}}\left(\mathrm{H}_{2} \mathrm{O}\right)\left(\mathrm{L}^{1}\right)\right]^{2+}$ with $\mathrm{ClO}_{3}^{-}$requires a highly endergonic displacement of water $\left(\Delta \mathrm{G}_{\mathrm{fic}}\right)$, which most probably originates from the fact that $\mathrm{HClO}_{3}$ is a much stronger acid than $\mathrm{HClO}_{2}$ and preferentially exists in the $\mathrm{ClO}_{3}^{-}$form. Hence although $\mathrm{ClO}_{2}^{-}$can react to form an iron(IV)-oxo species, reaction with $\mathrm{ClO}_{3}^{-}$by oxygen atom transfer to an iron(II) complex is not ther- 
mochemically feasible. A similar result was obtained for the formation of iron(IV)-oxo complexes from hypochlorite and an iron(II)-water complex..$^{40}$

The reactivity of $\left[\mathrm{Fe}^{\mathrm{IV}}(\mathrm{O})\left(\mathrm{L}^{1}\right)\right]^{2+}$ with a second molecule of $\mathrm{ClO}_{2}^{-}$was considered by two distinct reaction mechanisms; electron transfer (ET) and oxygen atom transfer (OAT), Figure 6. In these reaction steps, aside from the thermodynamic aspects, the kinetics of the reaction are of interest. Barriers to electron transfer were calculated using the Marcus model as described above, with a barrier of $10.1 \mathrm{kcal} \mathrm{mol}{ }^{-1}$ predicted for the reaction of $\left[\mathrm{Fe}^{\mathrm{IV}}(\mathrm{O})\left(\mathrm{L}^{1}\right)\right]^{2+}$ with $\mathrm{ClO}_{2}^{-}$, whereas for $\left[\mathrm{Fe}^{\mathrm{IV}}(\mathrm{O})\left(\mathrm{N}_{4} \mathrm{Py}\right)\right]^{2+}$ with $\mathrm{ClO}_{2}^{-}$a barrier of $17.0 \mathrm{kcal} \mathrm{mol}^{-1}$ is found. These values imply that both $\left[\mathrm{Fe}^{\mathrm{IV}}(\mathrm{O})\left(\mathrm{L}^{1}\right)\right]^{2+}$ and $\left[\mathrm{Fe}^{\mathrm{IV}}(\mathrm{O})\left(\mathrm{N}_{4} \mathrm{Py}\right)\right]^{2+}$ are able to react with $\mathrm{ClO}_{2}^{-}$by one-electron transfer, whereby the former will react faster than the latter. The free energies of activation for electron transfer are within $2 \mathrm{kcal} \mathrm{mol}^{-1}$ of the electron transfer driving forces and hence give only a minor change to the thermodynamically calculated energetics. These electron transfer barriers are in good quantitative agreement with the rate constants reported in Figure 2. Furthermore, the studies imply faster electron transfer for $\left[\mathrm{Fe}^{\mathrm{IV}}(\mathrm{O})\left(\mathrm{L}^{1}\right)\right]^{2+}$ than for $\left[\mathrm{Fe}^{\mathrm{IV}}(\mathrm{O})\left(\mathrm{N}_{4} \mathrm{Py}\right)\right]^{2+}$. Indeed, the reported $\mathrm{Fe}^{\mathrm{III}} / \mathrm{Fe}^{\mathrm{IV}}$ redox potentials of the $\mathrm{L}^{1}$ and $\mathrm{N}_{4} \mathrm{Py}$ systems confirm that this should be the case. ${ }^{18}$ In particular, a slightly higher electron affinity for $\left[\mathrm{Fe}^{\mathrm{IV}}(\mathrm{O})\left(\mathrm{L}^{1}\right)\right]^{2+}$ as compared to $\left[\mathrm{Fe}^{\mathrm{IV}}(\mathrm{O})\left(\mathrm{N}_{4} \mathrm{Py}\right)\right]^{2+}$ by $0.09 \mathrm{eV}$ is calculated, whereas the experimentally reported redox potential difference is 0.08 $\mathrm{eV}^{18}$ The calculated free energies of activation for electron transfer imply that these reactions should be rapid as well as spontaneous at room temperature.
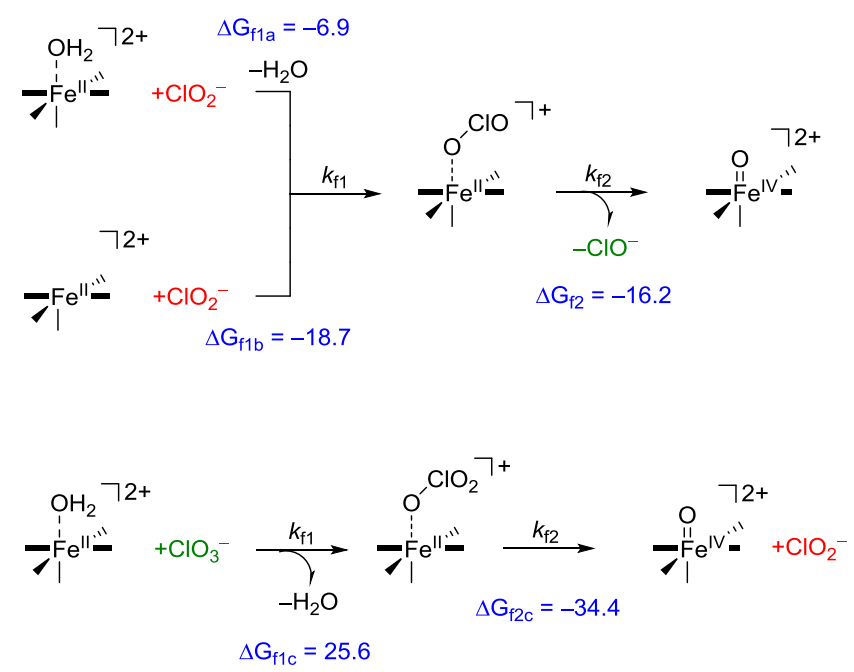

Figure 5. Reaction free energies for the individual steps leading to the formation of $\left[\mathrm{Fe}^{\mathrm{IV}}(\mathrm{O})\left(\mathrm{L}^{1}\right)\right]^{2+}$ from $\left[\mathrm{Fe}^{\mathrm{II}}\left(\mathrm{H}_{2} \mathrm{O}\right)\left(\mathrm{L}^{1}\right)\right]^{2+}$ and $\mathrm{ClO}_{2}^{-}$. Free energies given for systems with ligand $\mathrm{L}^{1}$ are in $\mathrm{kcal} \mathrm{mol}^{-1}$ and contain entropic, thermal and solvent effects.
In addition, the oxygen atom transfer pathway from $\left[\mathrm{Fe}^{\mathrm{IV}}(\mathrm{O})\left(\mathrm{L}^{1}\right)\right]^{2+}$ and $\left[\mathrm{Fe}^{\mathrm{IV}}(\mathrm{O})\left(\mathrm{N}_{4} \mathrm{Py}\right)\right]^{2+}$ to $\mathrm{ClO}_{2}^{-}$was explored initially by calculation of long range reactant complexes followed by a constraint geometry scan whereby one degree of freedom (the $\mathrm{Cl}-\mathrm{O}$ distance) was fixed and all other coordinates minimized. The maximum of these geometry scans were subjected to a transition state search. A transition state was not found in the triplet spin state and the geometry scan led to a repulsive product state that after optimization fell back to reactants. On the quintet spin state surface a stable OAT transition state ${ }^{5} \mathrm{TS}_{\mathrm{OAT}}$ at $+11.8 \mathrm{kcal} \mathrm{mol}^{-1}$ above the reactants was obtained, see Figure 6.

The structure is characterized by a low imaginary frequency for the $\mathrm{Cl}-\mathrm{O}$ stretch and $\mathrm{Fe}-\mathrm{O}$ elongation. In the transition state the $\mathrm{Fe}-\mathrm{O}$ bond is relatively long $(2.087 \AA)$, which matches previous studies on substrate sulfoxidation and aromatic hydroxylation barriers of nonheme iron(IV)-oxo oxidants in the quintet spin state. ${ }^{41,42}$

In the case of ${ }^{3,5}\left[\mathrm{Fe}^{\mathrm{IV}}(\mathrm{O})\left(\mathrm{N}_{4} \mathrm{Py}\right)\right]^{2+}---\mathrm{ClO}_{2}{ }^{-}$, the geometry scans led to a maximum with extremely high energy (well over $45 \mathrm{kcal} \mathrm{mol}^{-1}$ ) and we were unable to characterize its transition state. Probably this has to do with stereochemical repulsions of the approach of the substrate with the bispidine ligand system that prevent the ideal geometry for the transition state. Nevertheless, the geometry scan clearly identifies a high energy pathway for OAT. Indeed, the thermochemistry for OAT gives an overall strongly endergonic reaction for the $\mathrm{N}_{4}$ Py complex $\left(\Delta \mathrm{G}_{\mathrm{OAT}}=45.3\right.$ kcal $\mathrm{mol}^{-1}$ ), whereas it is only slightly endergonic for the bispidine complex, $\left[\mathrm{Fe}^{\mathrm{IV}}(\mathrm{O})\left(\mathrm{L}^{1}\right)\right]^{2+}$ at $\Delta \mathrm{G}_{\mathrm{OAT}}=+8.8 \mathrm{kcal}$ $\mathrm{mol}^{-1}$. The driving forces for the two oxygen atom transfer processes, therefore, imply that it is an energetically accessible process for $\left[\mathrm{Fe}^{\mathrm{IV}}(\mathrm{O})\left(\mathrm{L}^{1}\right)\right]^{2+}$, but most probably not for $\left[\mathrm{Fe}^{\mathrm{IV}}(\mathrm{O})\left(\mathrm{N}_{4} \mathrm{Py}\right)\right]^{2+}$, where barriers well in access of 45 $\mathrm{kcal}^{\mathrm{mol}}{ }^{-1}$ are expected on all spin state surfaces. These oxygen atom transfer barriers are larger than those anticipated from the experimental rate constants reported above, which may be the result of the lack of polarization or the environment in the calculations.

The studies described in Figure 6 imply that the reaction rates for ET and OAT will be competitive for $\left[\mathrm{Fe}^{\mathrm{IV}}(\mathrm{O})\left(\mathrm{L}^{1}\right)\right]^{2+}$ with similar driving forces and reaction rate constants, whereas $\left[\mathrm{Fe}^{\mathrm{IV}}(\mathrm{O})\left(\mathrm{N}_{4} \mathrm{Py}\right)\right]^{2+}$ at room temperature can only react via one-electron transfer because the driving force for the OAT reaction is substantially greater than that for ET. The reason for this difference in reactivity of bispidine and $\mathrm{N}_{4} \mathrm{Py}$ complexes stems from the fact that the $\mathrm{N}_{4} \mathrm{Py}$ complexes are weaker oxidants, specifically for oxygen atom transfer reactions, than the ferryl-bispidine complexes. For example, low rate constants for the reaction of $\left[\mathrm{Fe}^{\mathrm{IV}}(\mathrm{O})\left(\mathrm{N}_{4} \mathrm{Py}\right)\right]^{2+}$ with parasubstituted thioanisoles were reported. ${ }^{43}$ 


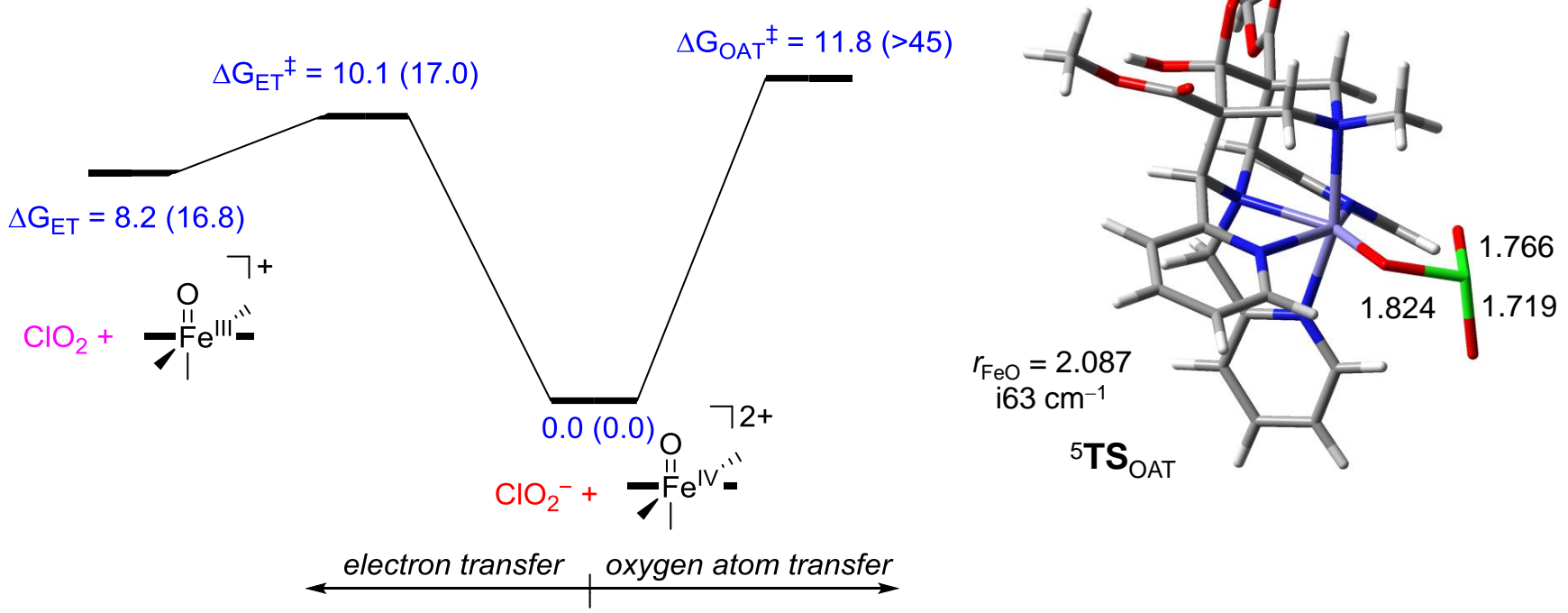

Figure 6. Bifurcation pathways for the reaction of $\mathrm{ClO}_{2}{ }^{-}$with $\left[\mathrm{Fe}^{\mathrm{IV}}(\mathrm{O})\right]^{2+}$ complexes going through electron transfer (pathway to the left) or oxygen atom transfer (pathway to the right). Free energies are in $\mathrm{kcal} \mathrm{mol}^{-1}$ and contain zero-point, entropic, thermal and solvent corrections. Data out of parenthesis are given for ligand $\mathrm{L}^{1}$, whereas values in parenthesis use $\mathrm{N}_{4} \mathrm{Py}$ instead. Optimized transition state for OAT is given with bond lengths in angstroms and the imaginary frequency in wave numbers.

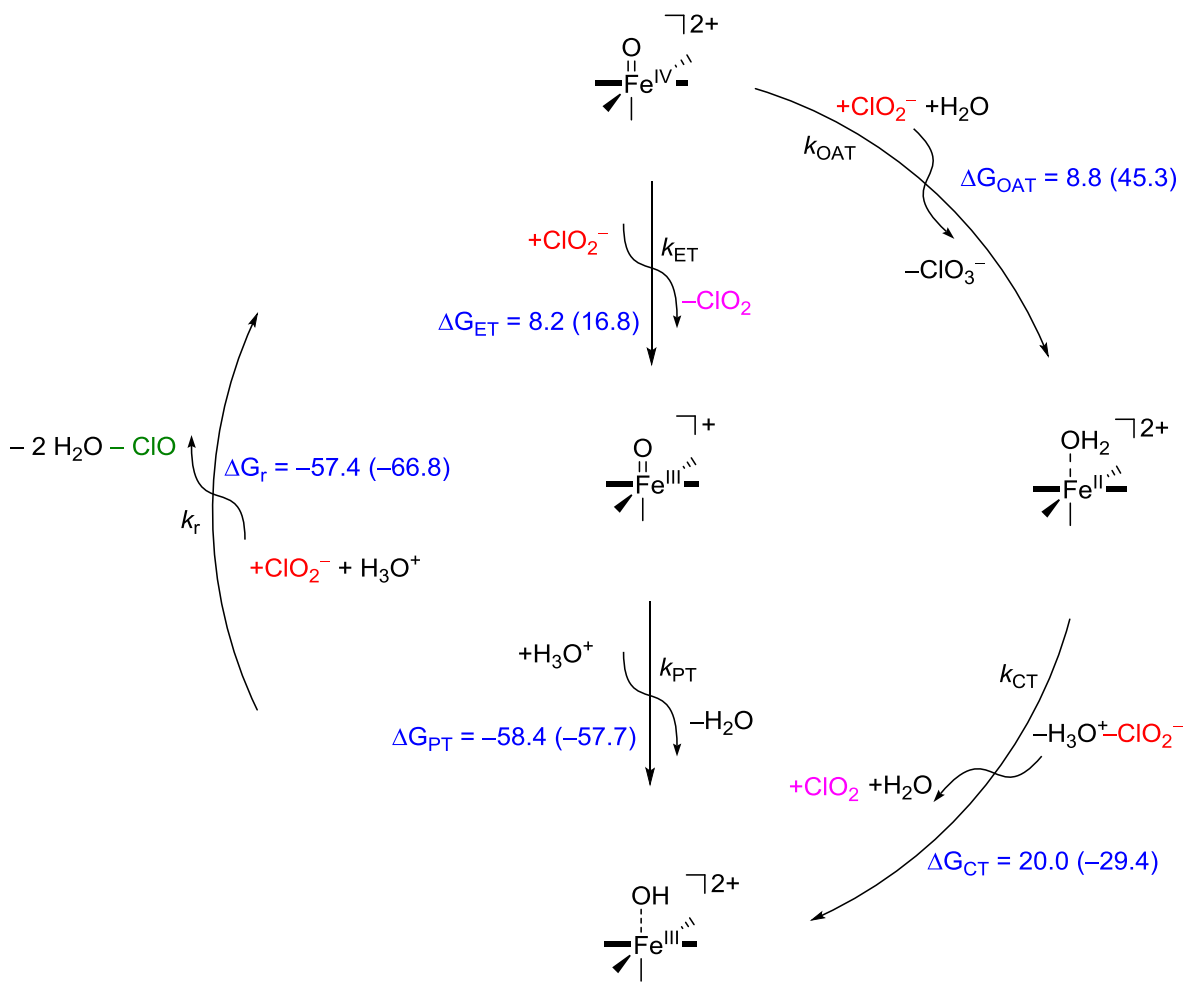

Figure 7. DFT calculated free energies of individual reaction steps. All values are in kcal mol ${ }^{-1}$ and contain zero-point, entropic, thermal and solvent corrections. Data outside of the parentheses are associated with the complex of ligand $\mathrm{L}^{1}$, whereas data within the parentheses refer to complexes of $\mathrm{N}_{4} \mathrm{Py}$. 
A similar bifurcated mechanism was recently found for iron(IV)-oxo versus iron(IV)-imido reactivity with sulfides, where the latter more efficiently performing a twoelectron transfer process. ${ }^{21}$ That the $\mathrm{N}_{4} \mathrm{Py}$ complex reacts preferentially through single-electron transfer pathways, therefore, is not due to an increased electron affinity, but mostly is a result of the destabilization of the OAT pathway. As such, minor differences in ligand structure drive reactions via different pathways and give variations in product distributions. This also means that the ligand system can be modified based on the required product distributions - provided one understands the correlation between structure and reactivity.

The full reaction cycles leading to $\mathrm{ClO}_{2}{ }^{-}$deactivation by $\left[\mathrm{Fe}^{\mathrm{II}}\left(\mathrm{L}^{1}\right)\right]^{2+}$ and $\left[\mathrm{Fe}^{\mathrm{II}}\left(\mathrm{N}_{4} \mathrm{Py}\right)\right]^{2+}$ were calculated, Figure 7 . As discussed above, the reaction is initiated upon displacement of the coordinated solvent of the iron(II) complex by $\mathrm{ClO}_{2}^{-}$followed by $\mathrm{Cl}-\mathrm{O}$ bond cleavage to form an iron(IV)-oxo species and $\mathrm{ClO}^{-}$with the reaction rate $\mathrm{k}_{\mathrm{f}}$. Note that in an acetate buffer, $\mathrm{ClO}_{2}{ }^{-}$can also react with acetate to form peracetate in an almost thermoneutral process, which may be another source for the formation of an iron(IV)-oxo species. Thereafter, the reaction pathway bifurcates into two reaction channels, namely electron transfer (ET, top) with rate constant $\mathrm{k}_{\mathrm{ET}}$ and oxygen atom transfer (OAT, bottom) with rate constant $\mathrm{k}_{\mathrm{OAT}}$. The electron transfer processes forms $\mathrm{ClO}_{2}$ and $\left[\mathrm{Fe}^{\mathrm{III}}(\mathrm{O})\right]^{+}$, which under acidic conditions is protonated to form an iron(III)-hydroxo complex via a proton-transfer reaction rate $\mathrm{k}_{\mathrm{PT}}$. The latter is a highly exergonic reaction step and is not expected to affect the overall reaction rate. The alternative OAT reaction leads to an iron(II)-aqua complex and releases $\mathrm{ClO}_{3}^{-}$. The $\left[\mathrm{Fe}^{\mathrm{II}}\left(\mathrm{H}_{2} \mathrm{O}\right)\right]^{2+}$ complex is converted to the iron(III)-hydroxo product in an electrontransfer reaction with $\mathrm{ClO}_{2}$ followed by deprotonation via reaction rate $\mathrm{k}_{\mathrm{CT}}$.

In the case of $\left[\mathrm{Fe}^{\mathrm{II}}\left(\mathrm{H}_{2} \mathrm{O}\right)\left(\mathrm{L}^{1}\right)\right]^{2+}$, the reaction with $\mathrm{ClO}_{2}{ }^{-}$ to form a stable iron(IV)-oxo species is exergonic with a driving force of $23.1 \mathrm{kcal} \mathrm{mol}^{-1}$. The bifurcation pathways results in competition between ET and OAT, which have barriers within $1.5 \mathrm{kcal} \mathrm{mol}^{-1}$ and therefore a mixture of products can be expected. The iron(III)-oxo species formed after electron abstraction from substrate is protonated to form an iron(III)-hydroxo complex with large exergonicity and is converted back into an iron(IV)-oxo species by reaction with another molecule of $\mathrm{ClO}_{2}^{-}$and $\mathrm{H}_{3} \mathrm{O}^{+}$. The overall reaction stoichiometry for the electron transfer pathway is given in Eq 6 and yields $\mathrm{ClO}_{2}$ as well as $\mathrm{Cl}^{-}$products. However, as shown previously, ${ }^{44}$ and also confirmed by DFT here, $\mathrm{ClO}^{-}$reacts with another iron(II) complex to form an iron(IV)-oxo species and $\mathrm{Cl}^{-}$. Therefore, a reaction pathway that follows the electron transfer channel will use two molecules of $\mathrm{ClO}_{2}^{-}$to form two molecules of iron(IV)-oxo and a $\mathrm{Cl}^{-}$. Each iron(IV)-oxo reacts with one molecule of $\mathrm{ClO}_{2}{ }^{-}$to form $\mathrm{ClO}_{2}$. As such a max- imum yield of $50 \%$ can be achieved for the reaction shown in Figure 7 .

$$
\begin{aligned}
& 2\left[\mathrm{Fe}^{\mathrm{II}}\left(\mathrm{H}_{2} \mathrm{O}\right)\left(\mathrm{L}^{1}\right)\right]^{2+}+3 \mathrm{ClO}_{2}^{-}+2 \\
& {\left[\mathrm{Fe}^{\mathrm{III}}(\mathrm{OH})\left(\mathrm{L}^{1}\right)\right]^{2+}+2 \mathrm{ClO}_{2}+\mathrm{Cl}^{-}+2 \mathrm{H}_{2} \mathrm{O} \mathrm{O}^{+} \rightarrow 2}
\end{aligned}
$$

The alternative reaction after OAT has a high endergonicity for charge transfer from $\left[\mathrm{Fe}^{\mathrm{II}}\left(\mathrm{H}_{2} \mathrm{O}\right)\left(\mathrm{L}^{1}\right)\right]^{2+}$ to $\mathrm{ClO}_{2}$. Instead, the $\left[\mathrm{Fe}^{\mathrm{II}}\left(\mathrm{H}_{2} \mathrm{O}\right)\left(\mathrm{L}^{1}\right)\right]^{2+}$ will react with $\mathrm{ClO}_{2}{ }^{-}$to form another iron(IV)-oxo complex. The overall reaction stoichiometry for the process involving the OAT pathway is essentially disproportionation of $\mathrm{ClO}_{2}^{-}$into $\mathrm{ClO}^{-}$and $\mathrm{ClO}_{3}{ }^{-}$catalyzed by an iron(II) center, Eq 7. Indeed, the disproportionation reaction is calculated to have a driving force of $\Delta \mathrm{G}_{\text {disproportionation }}=-14 \cdot 3 \mathrm{kcal} \mathrm{mol}^{-1}$.

$$
{ }_{2} \mathrm{ClO}_{2}^{-} \rightarrow \mathrm{ClO}^{-}+\mathrm{ClO}_{3}^{-}
$$

The computational modelling shows that multiple products are expected from the reaction of $\mathrm{ClO}_{2}^{-}$on iron(II) centers. In particular, $\left[\mathrm{Fe}^{\mathrm{II}}\left(\mathrm{L}^{1}\right)\right]^{2+}$ is expected to give a mixture of products due to competition between the barriers to each pathway and yield $\mathrm{ClO}_{2}, \mathrm{ClO}^{-}, \mathrm{ClO}$ and $\mathrm{ClO}_{3}^{-}$products, whereas $\left[\mathrm{Fe}^{\mathrm{II}}\left(\mathrm{N}_{4} \mathrm{Py}\right)\right]^{2+}$ will give products through the $\mathrm{k}_{\mathrm{ET}}$ process only and not $\mathrm{ClO}_{3}{ }^{-}$. The thermochemical analysis from Figure 7 is in good agreement with the product distributions in Figure 4, where a significant amount of $\mathrm{ClO}_{3}{ }^{-}$was obtained for the bispidine complex but none for $\left[\mathrm{Fe}^{\mathrm{Il}}\left(\mathrm{N}_{4} \mathrm{Py}\right)\right]^{2+}$.

The reactivity differences and the reason the bispidine complex reacted via multiple reaction channels, in contrast to the $\mathrm{N}_{4} \mathrm{Py}$ complex, were rationalized through a valence bond curve crossing diagram, Figure 8 . These diagrams have been used previously to establish the intrinsic properties of the oxidant and reductant that determine reaction processes and, for instance, enabled us to predict reactivity trends and rate constants. ${ }^{45}$

The VB diagrams start on the bottom-left with the reactant configuration, which in this case is the iron(IV)-oxo species and $\mathrm{ClO}_{2}{ }^{-}$. The iron(IV)-oxo species is in a triplet spin ground state with orbital occupation $\pi_{\mathrm{xz}}{ }^{2} \pi_{\mathrm{yz}}{ }^{2} \pi^{*}{ }_{\mathrm{xy}}{ }^{2}$ $\pi_{\mathrm{xz}}^{*} \pi^{*}{ }_{\mathrm{yz}}$. Slightly higher in energy is a quintet spin state with $\pi_{\mathrm{xz}}{ }^{2} \pi_{\mathrm{yz}}{ }^{2} \pi^{*}{ }_{\mathrm{xy}}{ }^{1} \pi^{*}{ }_{\mathrm{xz}}{ }^{1} \pi^{*}{ }_{\mathrm{yz}}{ }^{1} \sigma^{*}{ }_{\mathrm{zz}}{ }^{1}{ }^{45}$ Panel (a) in Figure 8 gives a mechanism for single electron transfer from $\mathrm{ClO}_{2}{ }_{2}^{-}$ to iron(IV)-oxo species and lead to the electron-transfer products $\mathrm{ClO}_{2}$ and $\left[\mathrm{Fe}^{\mathrm{III}}(\mathrm{O})\right]^{+}$. The two VB curves for reactant and product cross and lead to an avoided crossing and a transition state for electron transfer. Generally, the curve crossing energy is a fraction of the excitation energy in the reactant complex from the reactant electronic configuration to the product electronic configuration. As such the electronic differences between the reactant and product wave functions determine the height of the reaction barrier. 
(a)

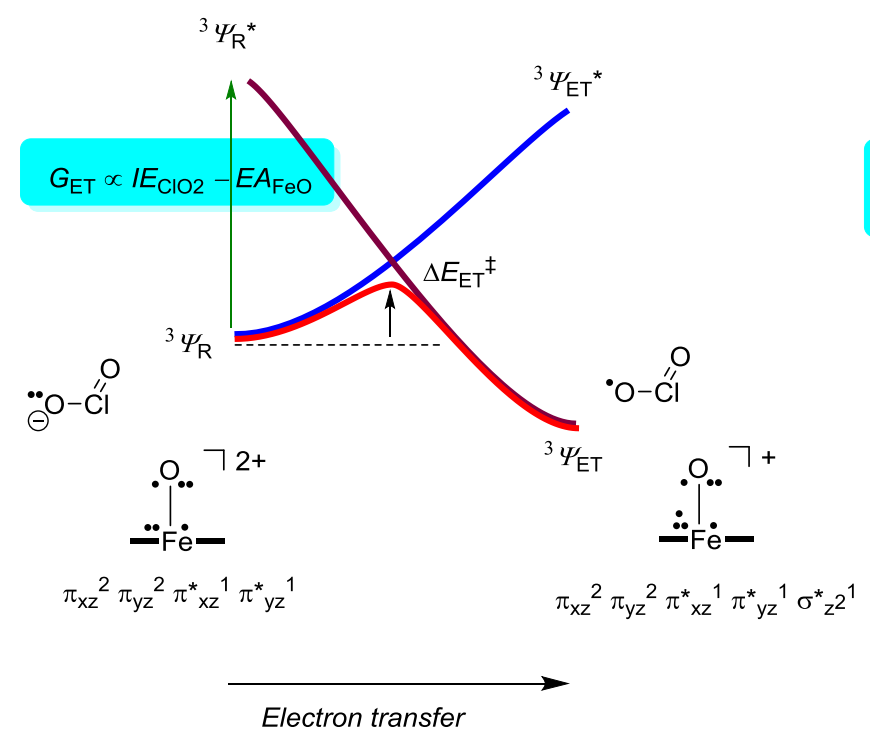

(b)

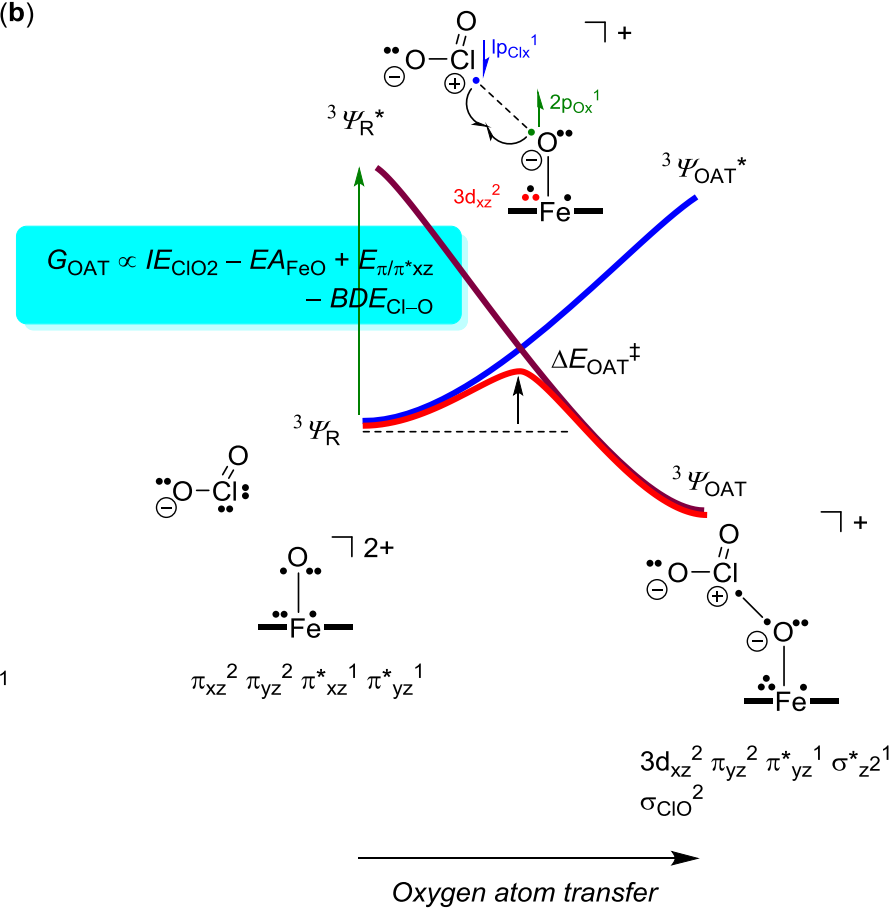

Figure 8. Valence bond curve crossing diagrams explaining the differences for the ET and OAT reaction steps.

Therefore, the one-electron transfer process will simply be determined by the ionization energy of $\mathrm{ClO}_{2}{ }^{-}\left(\mathrm{IE}_{\mathrm{ClO}_{2}}\right)$ and the electron affinity of the iron(IV)-oxo complex $\left(\mathrm{EA}_{\mathrm{FeO}}\right), \mathrm{Eq} 8$. We calculated the electron affinities of the two iron(IV)-oxo complexes as well as the ionization energy of $\mathrm{ClO}_{2}{ }^{-}$and find diabatic values of $\Delta \mathrm{E}+\mathrm{ZPE}+\mathrm{E}_{\text {solv }}=$ $121.7 \mathrm{kcal} \mathrm{mol}^{-1}\left(\mathrm{IE}_{\mathrm{ClO}_{2}}\right)$, and 90.1 and $81.8 \mathrm{kcal} \mathrm{mol}^{-1}$ for the EA of $\left[\mathrm{Fe}^{\mathrm{IV}}(\mathrm{O})\left(\mathrm{L}^{1}\right)\right]^{2+}$ and $\left[\mathrm{Fe}^{\mathrm{IV}}(\mathrm{O})\left(\mathrm{N}_{4} \mathrm{Py}\right)\right]^{2+}$, respectively.

As such, the VB curve crossing diagram predicts a $\mathrm{G}_{\mathrm{ET}}=$ 31.6 and $39.9 \mathrm{kcal} \mathrm{mol}^{-1}$ for the bispidine and $\mathrm{N}_{4} \mathrm{Py}$ complexes. In general, the barrier height is one third of the promotion gap, ${ }^{47}$ and, therefore, the VB diagram predicts electron transfer barriers of $\Delta \mathrm{E}^{\ddagger}=10.5$ and $13.3 \mathrm{kcal} \mathrm{mol}^{-1}$ for the reactions involving the bispidine and $\mathrm{N}_{4} \mathrm{Py}$ ligated systems, respectively. These values are in good quantitative agreement with the relative barrier heights discussed above in Figures 5 and 6.

$$
\mathrm{G}_{\mathrm{ET}} \propto \mathrm{IE}_{\mathrm{ClO}_{2}}-\mathrm{EA}_{\mathrm{FeO}}
$$

Figure $8 \mathrm{~b}$ shows the VB curve diagram for the oxygen atom transfer from iron(IV)-oxo to $\mathrm{ClO}_{2}{ }^{-}$, which shows resemblance to schemes rationalizing substrate sulfoxidation by iron(IV)-oxo complexes. ${ }^{48}$ This process is a concerted reaction where a $\mathrm{Cl}-\mathrm{O}$ bond is formed in a single elementary step. Thus, $\mathrm{ClO}_{2}^{-}$is first ionized to $\mathrm{ClO}_{2}$ and the unpaired electron on the $\mathrm{Cl}$ atom forms a bond with an electron in a 2 p orbital on the oxygen atom. However, at the start of the reaction the oxygen $2 p$ orbitals are hybridized with $3 \mathrm{~d}$ orbitals of the metal. Therefore, one of the sets of $\pi_{\mathrm{xz}} / \pi^{*}{ }_{\mathrm{xz}}$ or $\pi_{\mathrm{yz}} / \pi^{*}$ yz pairs of orbitals will split back into atomic orbitals to give a singly occupied $2 \mathrm{p}$ orbital on the oxygen atom and a doubly occupied $3 \mathrm{~d}$ orbital on the metal, i.e. $3 \mathrm{~d}_{\mathrm{xz}}{ }^{2} 2 \mathrm{p}_{\mathrm{x}}{ }^{1}$. Upon oxidation of $\mathrm{ClO}_{2}{ }^{-}$, however, one electron will move to the iron that is reduced from iron(IV) to iron(III). Consequently, the promotion gap for the oxygen atom transfer process will depend on the ionization energy $\left(\mathrm{IE}_{\mathrm{ClO}_{2}}\right)$ of $\mathrm{ClO}_{2}{ }^{-}$as well as the reduction of the iron(IV)-oxo to iron(III)-oxo, $\mathrm{EA}_{\mathrm{FeO}}$, Eq 9. Additional energy costs incurred in this process relate to the breaking of the $\pi_{\mathrm{xz}} / \pi^{*}{ }_{\mathrm{xz}}$ orbitals $\left(\mathrm{E}_{\pi / \pi^{*} \mathrm{xz}}\right)$, but also energy will be released due to the formation of the $\mathrm{Cl}-\mathrm{O}$ bond.

$$
\mathrm{G}_{\mathrm{OAT}} \propto \mathrm{IE}_{\mathrm{ClO}_{2}}-\mathrm{EA}_{\mathrm{FeO}}+\mathrm{E}_{\pi / \pi^{*} \mathrm{xz}}-\mathrm{BDE}_{\mathrm{Cl}-\mathrm{O}}
$$

The $\pi_{\mathrm{xz}} / \pi^{*}{ }_{\mathrm{xz}}$ and $\pi_{\mathrm{yz}} / \pi_{\mathrm{yz}}^{*}$ energy gaps at $\mathrm{UB}_{3} \mathrm{LYP} / \mathrm{BS}_{2}+$ solvent are 70.6 and $74.0 \mathrm{kcal} \mathrm{mol}^{-1}$ for ${ }^{3}\left[\mathrm{Fe}^{\mathrm{IV}}(\mathrm{O})\left(\mathrm{L}^{1}\right)\right]^{2+}$, whereas values of 102.0 and $103.1 \mathrm{kcal} \mathrm{mol}^{-}$ ${ }^{1}$ are found for ${ }^{3}\left[\mathrm{Fe}^{\mathrm{IV}}(\mathrm{O})\left(\mathrm{N}_{4} \mathrm{Py}\right)\right]^{2+}$. The diabatic ionization energy of $\mathrm{ClO}_{2}^{-}$is $121.7 \mathrm{kcal} \mathrm{mol}^{-1}$, while the vertical electron affinity of $\left[\mathrm{Fe}^{\mathrm{IV}}(\mathrm{O})\left(\mathrm{L}^{1}\right)\right]^{2+}$ and $\left[\mathrm{Fe}^{\mathrm{IV}}(\mathrm{O})\left(\mathrm{N}_{4} \mathrm{Py}\right)\right]^{2+}$ are 90.1 and $81.8 \mathrm{kcal} \mathrm{mol}^{-1}$, respectively. Based on these numbers and the calculated $\mathrm{Cl}-\mathrm{O}$ bond strength of 56.7 $\mathrm{kcal} \mathrm{mol}^{-1}$ we estimate a value of $\mathrm{G}_{\mathrm{OAT}}$ that is $24 \mathrm{kcal} \mathrm{mol}^{-1}$ lower in energy for the reaction of $\left[\mathrm{Fe}^{\mathrm{IV}}(\mathrm{O})\left(\mathrm{L}^{1}\right)\right]^{2+}$ with 
$\mathrm{ClO}_{2}{ }^{-}$than the one where $\left[\mathrm{Fe}^{\mathrm{IV}}(\mathrm{O})\left(\mathrm{N}_{4} \mathrm{Py}\right)\right]^{2+}$ is involved in. Therefore, a difference in OAT barrier height of about 8 kcal mol ${ }^{-1}$ between the two oxidants is predicted, which would correspond to a rate enhancement of well over 700,0oo. Indeed, as shown above in Figure 6 and in agreement with the experimental data, $\left[\mathrm{Fe}^{\mathrm{IV}}(\mathrm{O})\left(\mathrm{N}_{4} \mathrm{Py}\right)\right]^{2+}$ does not react via oxygen atom transfer, but preferentially through one-electron transfer. The VB diagram shows that this is due to increased $\pi_{\mathrm{xz}} / \pi^{*}{ }_{\mathrm{xz}}$ energy splitting and a decreased electron affinity. As such the VB curve crossing diagram gives an explanation what the driving force for electron transfer versus oxygen atom transfer is and how the oxidants can be further modified to obtain the required product distributions.

\section{Conclusion.}

In summary, we present the first experimental and computational study of the selective oxidation of chlorite to chlorine dioxide. We show that the reaction can proceed via competing pathways, whereby the nature of the ligand system and the binding affinity for $\mathrm{ClO}_{\mathrm{x}}{ }^{-}$substrates determines the driving force and activation barriers to each reaction step. The proposed mechanisms were validated experimentally and the high-valent iron(IV)-oxo intermediate formed in situ was characterized experimentally.

\section{ASSOCIATED CONTENT}

Supporting Information. Details with additional experimental data, UV/Vis absorption spectroscopic and mass spectrometric data focused on the characterization and reactivity of iron(IV)-oxo complexes. Computational data including absolute and relative energies, group spin densities and charges as well as calculated reaction energies and Cartesian coordinates of optimized structures. This material is available free of charge via the Internet at http://pubs.acs.org.

\section{AUTHOR INFORMATION}

\section{Corresponding Authors}

* Sam de Visser (sam.devisser@manchester.ac.uk);

Chivukula V. Sastri (sastricv@iitg.ernet.in);

Peter Comba (peter.comba@aci.uni-heidelberg.de)

\section{Present Address}

${ }^{\S}$ Inorganic and Physical Chemistry Division, CSIR-Indian Institute of Chemical Technology, Hyderabad 500 607, India

\section{Author Contributions}

The manuscript was written through contributions of all authors. All authors have given approval to the final version of the manuscript.

\section{ACKNOWLEDGMENT}

Research support was provided by the Department of Science and Technology (SERB), India (EMR/2014/ooo279) and Council for Scientific \& Industrial Research (o1(2527)/11/EMR-II) to CVS. Technical support from Dr. L. Giribabu to CVS is duly acknowledged. The National Service of Computational Chemistry Software (NSCCS) is acknowledged for cpu time to SdV. ASF thanks the Tertiary Education Trust Fund for a studentship. The EU-COST network CM1oo3 on Biological Oxidation Reactions is thanked for a short-term scientific mission of DA and SdV. The European Research Council is acknowledged for funding (ERC-2011StG-279549 to WRB).

\section{ABBREVIATIONS}

$\mathrm{N}_{4} \mathrm{Py}=\mathrm{N}, \mathrm{N}$-bis(2-pyridylmethyl)-bis(2-pyridyl)methylamine; $\mathrm{L}^{1}=$ dimethyl 2,4-di(2-pyridyl)3-(pyridin-2-ylmethyl)-7methyl-3,7-diazabicyclo [3.3.1] nonan-9-one-1,5-dicarboxylate; $\mathrm{L}^{2}=$ dimethyl 2,4-di(2-pyridyl)-3-methyl-7-(pyridin-2ylmethyl)-3,7-diazabicyclo[3-3.1] nonan-9-one-1,5-

dicarboxylate; $\mathrm{ET}=$ electron transfer; OAT = oxygen atom transfer; DFT = density functional theory; ESI-MS = electrospray ionization-mass spectrometry. 


\section{REFERENCES}

1. See, e.g. (a) Kraut, D. A.; Carroll, K. S.; Herschlag, D. Challenges in Enzyme Mechanism and Energetics. Annu. Rev. Biochem. 2003, 72, 517-571. (b) Atkins, P. W.; Jones, L. Chemical Principles, W. H. Freeman and Co., New York, 2010. (c) Moran, L. A.; Horton, H. R.; Scrimgeour, K. G.; Perry, M. D. Principles of Biochemistry, $5^{\text {th }}$ Ed., Pearson, Boston, 2012.

2. (a) Sono, M.; Roach, M. P.; Coulter, E. D.; Dawson, J. H. Heme-Containing Oxygenases. Chem. Rev. 1996, 96, 2841-2888. (b) Groves, J. T. The Bioinorganic Chemistry of Iron in Oxygenases and Supramolecular Assemblie. Proc. Natl. Acad. Sci. USA 2003, 100, 3569-3574. (c) Meunier, B.; de Visser, S. P.; Shaik, S. Mechanism of Oxidation Reactions Catalyzed by Cytochrome P450 Enzymes. Chem. Rev. 2004, 104, 3947-3980. (d) Ortiz de Montellano, P. R., Ed., Cytochrome P450: Structure, Mechanism and Biochemistry, $3^{\text {rd }}$ Ed., Kluwer Academic/Plenum Publishers, New York, 2005. (e) Munro, A. W.; Girvan, H. M.; McLean, K. J. Variations on a (t)HemeNovel Mechanisms, Redox Partners and Catalytic Functions in the Cytochrome P450 Superfamily. Nat. Prod. Rep. 2007, 24, 585-609. (f) Grogan, G. Cytochromes P450: Exploiting Diversity and Enabling Application as Biocatalysts. Curr. Opin. Chem. Biol. 2011, 15, 241-248.

3. See, e.g., (a) Raven, E. L. Understanding Functional Diversity and Substrate Specificity in Haem Peroxidases: What can We Learn from Ascorbate Peroxidase? Nat. Prod. Rep. 2003, 20, 367-381. (b) Alfonso-Prieto, M.; Biarnés, X.; Vidossich, P.; Rovira, C. The Molecular Mechanism of the Catalase Reaction. J. Am. Chem. Soc. 20o9, 131, 11751-11761. (c) Colin, J.; Wiseman, B.; Switala, J.; Loewen, P. C.; Ivancich, A. Distinct Role of Specific Tryptophans in Facilitating Electron Transfer or as $[\mathrm{Fe}(\mathrm{IV})=\mathrm{O}$ Trp•] Intermediates in the Peroxidase Reaction of Bulkholderia Pseudomallei Catalase-Peroxidase: A Multifrequency EPR Spectroscopy Investigation. J. Am. Chem. Soc. 2009, 131, 8557-8563. (d) Kadish, K. M.; Smith, K. M.; Guilard, R., Eds., Handbook of Porphyrin Science, World Scientific Publishing Co., New Jersey, 2010. (e) Poulos, T. L. Heme Enzyme Structure and Function. Chem. Rev. 2014, 114, 3919-3962.

4. (a) Giardina, B.; Messana, I.; Scatena, R.; Castagnola, M. The Multiple Functions of Hemoglobin. Crit. Rev. Biochem. Mol. Biol. 1995, 30, 165-196. (b) Rivetti, C.; Mozzarelli, A.; Rossi, G. L.; Henry, E. R.; Eaton, W. A. Oxygen Binding by Single Crystals of Hemoglobin. Biochemistry 1993, 32, 2888-2906.

5. (a) Gray, H. B.; Winkler, J. R. Electron Transfer in Proteins. Annu. Rev. Biochem. 1996, 65, 537-561. (b) Quintanar, L.; Stoj, C.; Taylor, A. B.; Hart, P. J.; Kosman, D. J.; Solomon, E. I. Shall We Dance? How A Multicopper Oxidase Chooses Its Electron Transfer Partner. Acc. Chem. Res. 2007, 40, 445-452. (c) Siegbahn, P. E. M.; Blomberg, M. R. A. Quantum Chemical Studies of Proton-Coupled Electron Transfer in Metalloenzymes. Chem. Rev. 2010, 110, 7040-7061. (d) Weinberg, D. R.; Gagliardi, C. J.; Hull, J. F.; Murphy, C. F.; Kent, C. A.; Westlake, B. C.; Paul, A.; Ess, D. H.; McCafferty, D. G.; Meyer, T. J. Proton-Coupled Electron Transfer. Chem. Rev. 2012, 112, 4016-4093. (e) Ow, Y.-L. P.; Green, D. R.; Hao, Z.; Mak, T. W. Cytochrome c: Functions beyond Respiration. Nature Mol. Cell Biol. 2oo8, 9, 532-542. (f) Yoshikawa, S.; Shimada, A.
Reaction Mechanism of Cytochrome c Oxidase. Chem. Rev. 2015, 115, 1936-1989.

6. (a) Straganz, G. D.; Nidetzky, B. Variations of the 2-His-1carboxylate Theme in Mononuclear Non-Heme Fe ${ }^{\mathrm{II}} \mathrm{Oxy}-$ genases. Chem. Bio. Chem. 2oo6, 7, 1536-1548. (b) de Visser, S. P.; Kumar, D., Eds., Iron-containing enzymes: Versatile catalysts of hydroxylation reaction in nature, RSC Publishing, Cambridge (UK), 2011. (c) Blomberg, M. R. A.; Borowski, T.; Himo, F.; Liao, R.-Z.; Siegbahn, P. E. M. Quantum Chemical Studies of Mechanisms for Metalloenzymes. Chem. Rev. 2014, 114, 3601-3658. (d) Tchesnokov, E. P.; Fellner, M.; Siakkou, E.; Kleffmann, T.; Martin, L. W.; Aloi, S.; Lamont, I. L.; Wilbanks, S. M.; Jameson, G. N. L. The Cysteine Dioxygenase Homologue from Pseudomonas aeruginosa Is a 3-Mercaptopropionate Dioxygenase. J. Biol. Chem. 2015, 290, 24424-24437.

7. (a) Trewick, S. C.; Henshaw, T. F.; Hausinger, R. P.; Lindahl, T.; Sedgwick, B. Oxidative Demethylation by Escherichia coli AlkB Directly Reverts DNA Base Damage. Nature 2002, 419, 174-178. (b) Falnes, P. Ø.; Johansen, R. F.; Seeberg, E. AlkB-Mediated Oxidative Demethylation Reverses DNA Damage in Escherichia coli. Nature 2002, 419, 178-182. (c) O'Brien, P. J. Chem. Rev. 20o6, 106, 720-752. (d) Yi, C.; Yang, C. G.; He, C. A Non-Heme Iron-Mediated Chemical Demethylation in DNA and RNA. Acc. Chem. Res. 2009, 42, 519-529. (d) Liu, H.; Llano, J.; Gauld, J. W. A DFT Study of Nucleobase Dealkylation by the DNA Repair Enzyme AlkB. J. Phys. Chem. B 2009, 113, 48874898.

8. (a) Wu, M.; Moon, H.-S.; Begley, T. P.; Myllyharju, J.; Kivirikko, K. I. Mechanism-Based Inactivation of the Human Prolyl-4-hydroxylase by 5-Oxaproline-Containing Peptides: Evidence for a Prolyl Radical Intermediate. J. Am. Chem. Soc. 1999, 121, 587-588. (b) Hoffart, L. M.; Barr, E. W.; Guyer, R. B.; Bollinger Jr, J. M.; Krebs, C. Direct Spectroscopic Detection of a $\mathrm{C}-\mathrm{H}$-Cleaving HighSpin Fe(IV) Complex in a Prolyl-4-hydroxylase. Proc. Natl. Acad. Sci. USA 2006, 103, 14738-14743. (c) Seifert, A.; Katschinski, D. M.; Tonack, S.; Fischer, B.; Santos, A. N. Significance of Prolyl Hydroxylase 2 in the Interference of Aryl Hydrocarbon Receptor and Hypoxia-Inducible Factor-1 $\alpha$ Signaling. Chem. Res. Toxicol. 20o8, 21, 341-348.

9. See, e.g., (a) Johnson, D. C.; Dean, D. R.; Smith, A. D.; Johnson, M. K. Structure, Function, and Formation of Biological Iron-Sulfur Clusters. Annu. Rev. Biochem. 2005, 74, 247-281. (b) Volkov, A. N. Structure and Function of Transient Encounters of Redox Proteins. Acc. Chem. Res. 2015, 48, 3036-3043.

10. (a) Costas, M. Selective $\mathrm{C}-\mathrm{H}$ Oxidation Catalyzed by Metalloporphyrins. Coord. Chem. Rev. 2011, 255, 29122932. (b) Bruijnincx, P. C. A.; van Koten, G.; Klein Gebbink, R. J. M. Mononuclear Non-Heme Iron Enzymes with the 2-His-1-carboxylate Facial Triad: Recent Developments in Enzymology and Modeling Studies. Chem. Soc. Rev. 20o8, 37, 2716-2744. (c) Kryatov, S. V.; RybakAkimova, E. V.; Schindler, S. Kinetics and Mechanisms of Formation and Reactivity of Non-heme Iron Oxygen Intermediates. Chem. Rev. 2005, 105, 2175-2226. (d) McDonald, A. R.; Que Jr., L. High-Valent Nonheme IronOxo Complexes: Synthesis, Structure, and Spectroscopy. Coord. Chem. Rev. 2013, 257, 414-428. (e) Nam, W.; Lee, Y.-M.; Fukuzumi, S. Tuning Reactivity and Mechanism in Oxidation Reactions by Mononuclear Nonheme Iron(IV)Oxo Complexes. Acc. Chem. Res. 2o14, 47, 1146-1154. 
11. For selected examples, see, (a) Parsell, T. H.; Yang, M.-Y.; Borovik, A. S. C-H Bond Cleavage with Reductants: ReInvestigating the Reactivity of Monomeric $\mathrm{Mn}^{\text {III/IV }}-\mathrm{Oxo}$ Complexes and the Role of Oxo Ligand Basicity. J. Am. Chem. Soc. 2009, 131, 2762-2763. (b) Comba, P.; Kerscher, M. Computation of Structures and Properties of Transition Metal Compounds. Coord. Chem. Rev. 2009, 253, 564-574. (c) Sil, D.; Khan, F. S. T.; Rath, S. P. Axial Thiophenolate Coordination on Diiron(III)bisporphyrin: Influence of Heme-Heme Interactions on Structure, Function and Electrochemical Properties of the Individual Heme Center. Inorg. Chem. 2014, 53, 11925-11936.

12. Park, J.; Morimoto, Y.; Lee, Y.-M.; Nam, W.; Fukuzumi, S. Proton-Promoted Oxygen Atom Transfer vs ProtonCoupled Electron Transfer of a Non-Heme Iron(IV)-Oxo Complex. J. Am. Chem. Soc. 2012, 134, 3903-3911.

13. Song, W. J.; Ryu, Y. O.; Song, R.; Nam, W. Oxoiron(IV) Porphyrin $\pi$-Cation Radical Complexes with a Chameleon Behavior in Cytochrome $\mathrm{P} 450$ Model Reactions. J. Biol. Inorg. Chem. 2005, 10, 294-304.

14. (a) Vardhaman, A. K.; Barman, P.; Kumar, S.; Sastri, C. V.; Kumar, D.; de Visser, S. P. Comparison of the Reactivity of Nonheme Iron(IV)-Oxo versus Iron(IV)-Imido Complexes: Which is the Better Oxidant? Angew. Chem. Int. Ed. 2013, 52, 12288-12292. (b) Klinker, E. J.; Jackson, T. A.; Jensen, M. P.; Stubna, A.; Juhász, G.; Bominaar, E. L.; Münck, E.; Que Jr., L. A Tosylimido Analogue of a Nonheme Oxoiron(IV) Complex. Angew. Chem. Int. Ed. 20o6, 45, 7394-7397.

15. (a) Bender, K. S.; Shang, C.; Chakraborty, R.; Belchik, S. M.; Coates, J. D.; Achenbach, L. A. Identification, Characterization, and Classification of Genes Encoding Perchlorate Reductase. J. Bacteriol. 2005, 187, 5090-5096. (b) Steinberg, L. M.; Trimble, J. J.; Logan, B. E. Enzymes Responsible for Chlorate Reduction by Pseudomonas sp. are Different from Those Used for Perchlorate Reduction by Azospira sp. FEMS Microbiol. Lett. 2005, 247, 153-159.

16. (a) Mayfield, J. A.; Blanc, B.; Rodgers, K. R.; LukatRodgers, G. S.; DuBois, J. L. Peroxidase-Type Reactions Suggest a Heterolytic/Nucleophilic O-O Joining Mechanism in the Heme-Dependent Chlorite Dismutase. Biochemistry 2013, 52, 6982-6994. (b) Hofbauer, S.; Schaffner, I.; Furtmüller, P. G.; Obinger, C. Chlorite Dismutases - a Heme Enzyme Family for Use in Bioremediation and Generation of Molecular Oxygen. Biotechnol. J. 2014, 9, 461-473. (c) Dassama, L. M.; Yosca, T. H.; Conner, D. A.; Lee, M. H.; Blanc, B.; Streit, B. R.; Green, M. T.; DuBois, J. L.; Krebs, C.; Bollinger Jr, J. M. $\mathrm{O}_{2}$-Evolving Chlorite Dismutase as a Tool for Studying $\mathrm{O}_{2}$-Utilizing Enzymes. Biochemistry 2012, 51, 1607-1616.

17. Comba, P.; Kerscher, M.; Schiek, W. Bispidine Coordination Chemistry. Prog. Inorg. Chem. 2007, 55, 613-704.

18. Wang, D.; Ray, K.; Collins, M. J.; Farquhar, E. R.; Frisch, J. R.; Gómez, L.; Jackson, T. A.; Kerscher, M.; Waleska, A.; Comba, P.; Costas, M.; Que Jr., L. Nonheme Oxoiron(IV) Complexes of Pentadentate $\mathrm{N}_{5}$ Ligands: Spectroscopy, Electrochemistry, and Oxidative Reactivity. Chem. Sci. 2013, 4, 282-291.

19. Lubben, M.; Meetsma, A.; Wilkinson, E. C.; Feringa, B.; Que Jr., L. Nonheme Iron Centers in Oxygen Activation: Characterization of an Iron(III) Hydroperoxide Intermediate. Angew. Chem. Int. Ed. Engl. 1995, 34, 1512-1514.

2o. (a) Börzel, H.; Comba, P.; Hagen, K. S.; Lampeka, Y. D.; Lienke, A.; Linti, G.; Merz, M.; Pritzkow, H.; Tsymbal, L.
V. Iron Coordination Chemistry with Tetra-, Penta- and Hexadentate Bispidine-Type Ligands. Inorg. Chim. Acta. 2002, 337, 407-419. (b) Bukowski, M. R.; Comba, P.; Limberg, C.; Merz, M.; Que Jr., L.; Wistuba, T. Bispidine Ligand Effects on Iron/Hydrogen Peroxide Chemistry. Angew. Chem. Int. Ed. 2004, 43, 1283-1287.

21. Kumar, S.; Faponle, A. S.; Barman, P.; Vardhaman, A. K.; Sastri, C. V.; Kumar, D.; de Visser, S. P. Long-Range Electron Transfer Triggers Mechanistic Differences between Iron(IV)-Oxo and Iron(IV)-Imido Oxidants. J. Am. Chem. Soc. 2014, 136, 17102-17115.

22. Hicks, S. D.; Kim, D.; Xiong, S.; Medvedev, G. A.; Caruthers, J.; Hong, S.; Nam, W.; Abu-Omar, M. M. NonHeme Manganese Catalysts for On-Demand Production of Chlorine Dioxide in Water and Under Mild Conditions. J. Am. Chem. Soc. 2014, 136, 3680-3686.

23. Urone, P.; Bonde, E. Colorimetric Determination of Chlorates in Well Waters. Anal. Chem. 196o, 32, 1666-1668.

24. Frisch, M. J. Gaussian 09, revision D.o1; Gaussian, Inc., Wallingford, CT, 2009.

25. (a) Kumar, D.; Karamzadeh, B.; Sastry, G. N.; de Visser, S. P. What Factors Influence the Rate Constant of Substrate Epoxidation by Compound I of Cytochrome $\mathrm{P} 450$ and Analogous Iron(IV)-Oxo Oxidants? J. Am. Chem. Soc. 2010, 132, 7656-7667. (b) de Visser, S. P.; Quesne, M. G.; Martin, B.; Comba, P.; Ryde, U. Computational Modelling of Oxygenation Processes in Enzymes and Biomimetic Model Complexes. Chem. Commun. 2014, 50, 262-282.

26. (a) Becke, A. D. Density-Functional Thermochemistry. III. The Role of Exact Exchange. J. Chem. Phys. 1993, 98, 5648-5652. (b) Lee, C.; Yang, W.; Parr, R. G. Development of the Colle-Salvetti Correlation-Energy Formula into a Functional of the Electron Density. Phys. Rev. B 1988, 37, 785-789.

27. (a) Hay, P. J.; Wadt, W. R. Ab Initio Effective Core Potentials for Molecular Calculations. Potentials for $\mathrm{K}$ to $\mathrm{Au}$ Including the Outermost Core Orbitals. J. Chem. Phys. 1985, 82, 299-310. (b) Hehre, W. J.; Ditchfield, K.; Pople, J. A. Self-Consistent Molecular Orbital Methods. XII. Further Extensions of Gaussian-Type Basis Sets for Use in Molecular Orbital Studies of Organic Molecules. J. Chem. Phys. 1972, 56, 2257-2261.

28. (a) Vardhaman, A. K.; Sastri, C. V.; Kumar, D.; de Visser, S. P. Nonheme Ferric Hydroperoxo Intermediates are Efficient Oxidants of Bromide Oxidation. Chem. Commun. 2011, 47, 11044-11046. (b) Sainna, M. A.; Kumar, S.; Kumar, D.; Fornarini, S.; Crestoni, M. E.; de Visser, S. P. A Comprehensive Test Set of Epoxidation Rate Constants for Iron(IV)-Oxo Porphyrin Cation Radical Complexes. Chem. Sci. 2015, 6, 1516-1529.

29. (a) Becke, A. D. Density-Functional Exchange-Energy Approximation with Correct Asymptotic Behavior. Phys. Rev. A 1988, 38, 3098-3100. (b) Perdew, J. P. DensityFunctional Approximation for the Correlation Energy of the Inhomogeneous Electron Gas. Phys. Rev. B 1986, 33, 8822-8824.

30. Adamo, C.; Barone, V. toward Reliable Density Functional Methods without Adjustable Parameters: The PBEo Model. J. Chem. Phys. 1999, 110, 6158-6169.

31. Zhao, Y.; Truhlar, D. G. A New Local Density Functional for Main-Group Thermochemistry, Transition Metal Bonding, Thermochemical Kinetics, and Noncovalent Interactions. J. Chem. Phys. 2006, 125, 194101-194101. 
32. Perdew, J. P.; Wang, Y. Accurate and Simple Analytic Representation of the Electron-Gas Correlation Energy. Phys. Rev. B 1992, 45, 13244-13249.

33. Grimme, S.; Antony, J.; Ehrlich, S.; Krieg, H. A Consistent and Accurate $A b$ Initio Parametrization of Density Functional Dispersion Correction (DFT-D) for the 94 Elements H-Pu. J. Chem. Phys. 2010, 132, 154104-154104.

34. NIST Chemistry WebBook, NIST Standard Reference Database, Number 69, Linstrom, P. J.; Mallard, W. G., Eds., National Institute of Standards and Technology, Gaithersburg MD, 20899, http://webbook.nist.gov.

35. Ji, L.; Zhang, J.; Liu, W.; de Visser, S. P. Metabolism of Halogenated Alkanes by Cytochrome P450 Enzymes. Aerobic Oxidation versus Anaerobic Reduction. Chem. Asian J. 2014, 9, 1175-1182.

36. Clapper, T. W.; Gale, W. A. Encyclopedia of Chemical Technology, Kirk, R. E.; Othmer, D. F. (Eds), Wiley, New York, $2^{\text {nd }}$ Edn, 1964.

37. (a) Hicks, S. D.; Petersen, J. L.; Bougher, C. J.; Abu-Omar, M. M. Chlorite Dismutation to Chlorine Dioxide Catalyzed by a Water-Soluble Manganese Porphyrin. Angew. Chem. Int. Ed. 2011, 50, 699-702. (b) Hu, Z.; Du, H.; Man, W.-L.; Leung, C.-F.; Liang, H.; Lau, T.-C. Catalytic Reactions of Chlorite with a Polypyridylruthenium(II) Complex: Disproportionation, Chlorine Dioxide Formation and Alcohol Oxidation. Chem. Commun. 2012, 48, 11021104 .

38. Kaizer, J.; Klinker, E. J.; Oh, N. Y.; Rohde, J.-U.; Song, W. J.; Stubna, A.; Kim, J.; Münck, E.; Nam, W.; Que Jr., L. Nonheme $\mathrm{Fe}^{\mathrm{IV}} \mathrm{O}$ Complexes That Can Oxidize the $\mathrm{C}-\mathrm{H}$ Bonds of Cyclohexane at Room Temperature. J. Am. Chem. Soc 2004, 126, 472-473.

39. Roelfes, G.; Lubben, M.; Chen, K.; Ho, R. Y. N.; Meetsma, A.; Genseberger, S.; Hermant, R. M.; Hage, R.; Mandal, S. K.; Young Jr, V. G.; Zang, Y.; Kooijman, H.; Spek, A. L.; Que, Jr., L.; Feringa, B. L. Iron Chemistry of a Pentadentate Ligand That Generates a Metastable Fe ${ }^{\mathrm{III}}-\mathrm{OOH}$ Intermediate. Inorg. Chem. 1999, 38, 1929-1936.

40. Draksharapu, A.; Angelone, D.; Quesne, M. G.; Padamati, S. K.; Gómez, L.; Hage, R.; Costas, M.; Browne, W. R.; de Visser, S. P. Identification and Spectroscopic Characterization of Nonheme Iron(III) Hypochlorite Intermediates. Angew. Chem. Int. Ed. 2015, 54, 4357-4361.

41. Jaccob, M.; Comba, P.; Maurer, M.; Vadivelu, P.; Venuvanalingam, P. A Combined Experimental and Computational Study on the Sulfoxidation by HighValent Iron Bispidine Complexes. Dalton Trans. 2011, 40, 11276-11281.

42. (a) de Visser, S. P.; Oh, K.; Han, A.-R.; Nam, W. Combined Experimental and Theoretical Study on Aromatic Hydroxylation by Mononuclear Nonheme Iron(IV)-Oxo Complexes. Inorg. Chem. 2007, 46, 4632-4641. (b) Kumar, D.; Sastry, G. N.; de Visser, S. P. Effect of the Axial Ligand on Substrate Sulfoxidation Mediated by Iron(IV)-Oxo Porphyrin Cation Radical Oxidants. Chem. Eur. J. 2011, 17, 6196-6205.

43. Park, M. J.; Lee, J.; Suh. Y.; Kim, J.; Nam, W. Reactivities of Mononuclear Non-Heme Iron Intermediates Including Evidence that Iron(III)-Hydroperoxo Species Is a Sluggish Oxidant. J. Am. Chem. Soc. 2006, 128, 2630-2634.

44. Umile, T. P.; Wang, D.; Groves, J. T. Dissection of the Mechanism of Manganese Porphyrin-Catalyzed Chlorine Dioxide Generation. Inorg. Chem. 2011, 50, 10353-10362.
45. For selected examples, see (a) Shaik, S.; Kumar, D.; de Visser, S. P. A Valence Bond Modeling of Trends in Hydrogen Abstraction Barriers and Transition States of Hydroxylation Reactions Catalyzed by Cytochrome $\mathrm{P}_{450}$ Enzymes. J. Am. Chem. Soc. 20o8, 130, 10128-10140. (b) Ji, L.; Faponle, A. S.; Quesne, M. G.; Sainna, M. A.; Zhang, J.; Franke, A.; Kumar, D.; van Eldik, R.; Liu, W.; de Visser, S. P. Drug Metabolism by Cytochrome P45o Enzymes: What Distinguishes the Pathways Leading to Substrate Hydroxylation Over Desaturation? Chem. Eur. J. 2015, 21, 9083-9092. (c) Hernández-Ortega, A.; Quesne, M. G.; Bui, S.; Heyes, D. J.; Steiner, R. A.; Scrutton, N. S.; de Visser, S. P. Catalytic Mechanism of Cofactor-Free Dioxygenases and How They Circumvent Spin-Forbidden Oxygenation of Their Substrates. J. Am. Chem. Soc. 2015, 137, 7474-7487.

46. (a) de Visser, S. P. Differences in and Comparison of the Catalytic Properties of Heme and Non-Heme Enzymes with a Central Oxo-Iron Group. Angew. Chem. Int. Ed. 2006, 45, 1790-1793. (b) Quesne, M. G.; Latifi, R.; Gonzalez-Ovalle, L. E.; Kumar, D.; de Visser, S. P. Quantum Mechanics/Molecular Mechanics Study on the Oxygen Binding and Substrate Hydroxylation Step in AlkB Repair Enzymes. Chem. Eur. J. 2014, 20, 435-446.

47. Shaik, S. S. What Happens to Molecules as They React? A Valence Bond Approach to Reactivity. J. Am. Chem. Soc. 1981, 103, 3692-3701.

48. Shaik, S.; Lai, W.; Chen, H.; Wang, Y. The Valence Bond Way: Reactivity Patterns of Cytochrome P45o Enzymes and Synthetic Analogs. Acc. Chem. Res. 2010, 43, 11541165 . 
For Table of Contents only: This paper describes a novel mechanism of chlorite oxidation by iron(II) complexes and it is shown that two competing pathways for either oxygen atom transfer or electron transfer participate depending on the nature of the ligand system.

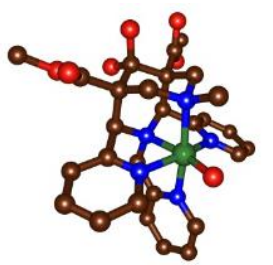

$\mathrm{ClO}_{3}^{-}$

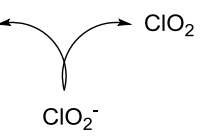

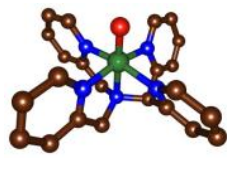

